This document is downloaded from DR-NTU (https://dr.ntu.edu.sg) Nanyang Technological University, Singapore.

The capital gains lock-in effect on earnings quality

Feng, Fan

2019

https://hdl.handle.net/10356/82301

https://doi.org/10.32657/10220/48116 




NANYANG TECHNOLOGICAL UNIVERSITY

SINGAPORE

THE CAPITAL GAINS LOCK-IN EFFECT ON EARNINGS QUALITY



FENG FAN

NANYANG BUSINESS SCHOOL

$T$
2
$Z$
2
2
$Z$
$Z$

2019 


\section{THE CAPITAL GAINS LOCK-IN EFFECT ON EARNINGS QUALITY}

\section{FENG FAN}

NANYANG BUSINESS SCHOOL

A thesis submitted to Nanyang Technological University in partial fulfillment of the requirements for the degree of Doctor of Philosophy

2019 


\section{Statement of Originality}

I hereby certify that the work embodied in this thesis is the result of original research, is free of plagiarised materials, and has not been submitted for a higher degree to any other University or Institution.

Feb-18-2019

Feb-18-2019
Faw Fang

Fan FENG 


\section{Supervisor Declaration Statement}

I have reviewed the content and presentation style of this thesis and declare it is free of plagiarism and of sufficient grammatical clarity to be examined. To the best of my knowledge, the research and writing are those of the candidate except as acknowledged in the Author Attribution Statement. I confirm that the investigations were conducted in accord with the ethics policies and integrity standards of Nanyang Technological University and that the research data are presented honestly and without prejudice.

$$
\text { Fets } 18.2019
$$

Feb-18-2019

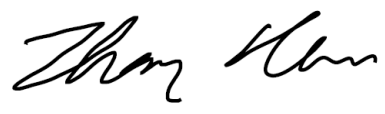

Huai ZHANG 


\section{Authorship Attribution Statement}

This thesis does not contain any materials from papers published in peerreviewed journals or from papers accepted at conferences in which I am listed as an author.

Feb-18-2019

Feb-18-2019
Faw tang

Fan FENG 


\section{Acknowledgements}

First of all, my deepest gratitude goes to my supervisor, Dr. Huai ZHANG, for his insightful guidance, invaluable feedback, and unwavering encouragement. He has walked with me through every stage of my research journey at NBS. He not only taught me how to critique studies, evaluate ideas, and write papers, but also guided me to grow as a researcher and as a person. I would especially like to offer my profound thanks to Dr. Stephen Geoffrey DIMMOCK for his insightful input, continued support, and generous help. His prudent attitude toward academic research deeply inspired me. I gratefully acknowledge him for his invaluable suggestions on my research and useful tips about the job market. I would like to convey my heartfelt gratitude to Dr. Rui SHEN who chaired my TAC and has provided me with a lot of support and help. I cannot refrain from mentioning Dr. Jiang LUO who greatly helped me to improve my thesis. Finally, I thank Dr. Hun Tong TAN for giving me solid training in behavioral accounting research.

I would especially like to thank my girlfriend Rosemary Jiaxu PENG for her love, support, and help. We have been in Singapore for four years. I hope and believe that we will be together for life. To my parents and grandparents, I owe a great debt of gratitude for their dedication and commitment to giving me the best education, their love, and their support.

During the past four years, NTU librarians, NBS administrative staffs, and GH2 technicians helped me a lot in terms of my academic research and on-campus living. Especially, I would like to extend my grateful thanks to Karen, Bee Hua, and Adeline.

The last but not the least, I would like to owe my sincere gratitude to my friends, who always do their best to help me and make me feel the warmth of life.

\section{For All, Thank You.}




\section{Table of Contents}

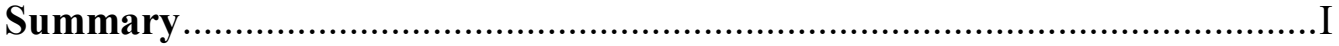



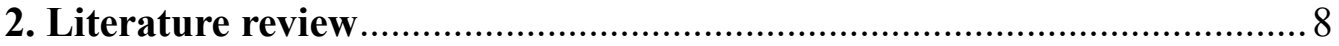

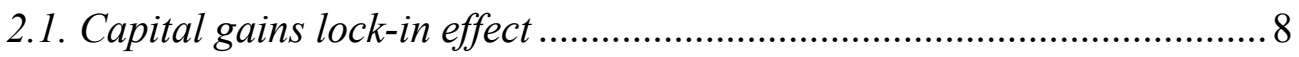

2.2. Tax and earnings management ............................................................ 10

2.3. Institutional investors and earnings management ............................... 12

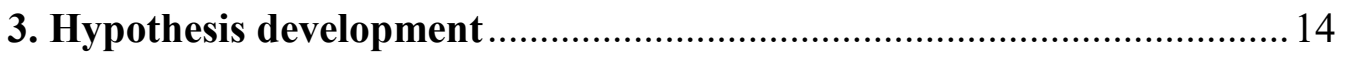

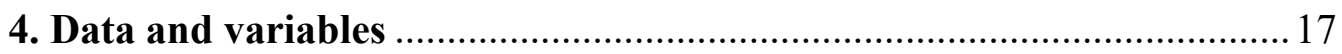

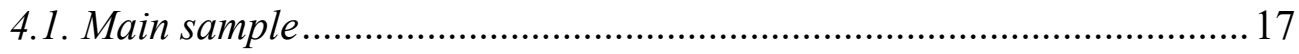

4.2. Description of the dependent variables ................................................. 18

4.2.1. Performance matched discretionary accruals ............................... 18

4.2.2. Accruals quality using McNichols (2002) modification of Dechow



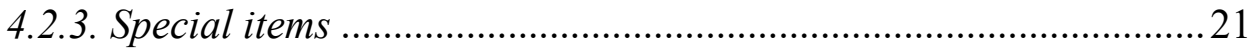

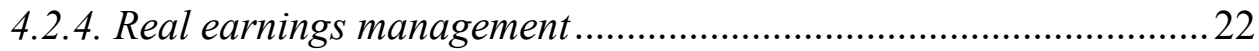



4.3. Description of the key explanatory variables ........................................26

4.4. Description of the control variables .....................................................28

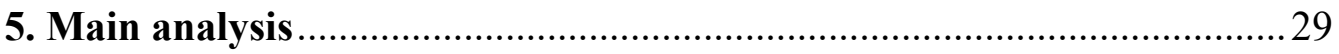

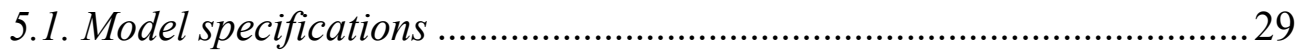

5.1.1. Performance matched discretionary accruals ................................ 30

5.1.2. Accruals quality using McNichols (2002) modification of Dechow and Dichev (2002) ................................................................... 32

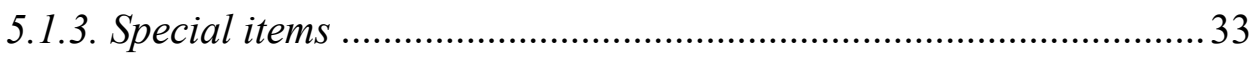

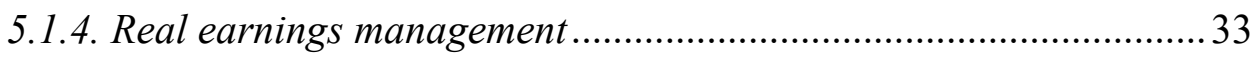

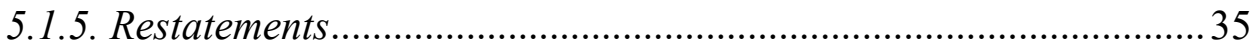

6. Capital gains lock-in and earnings quality: Evidence from tax rate change.

7. Mechanism of capital gains lock-in effect: Evidence on the monitoring





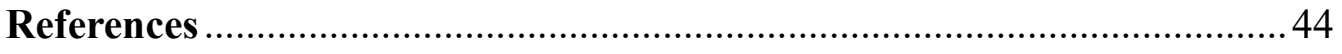

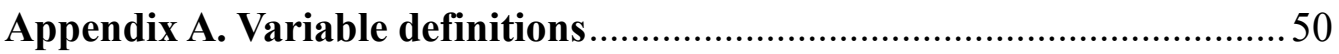

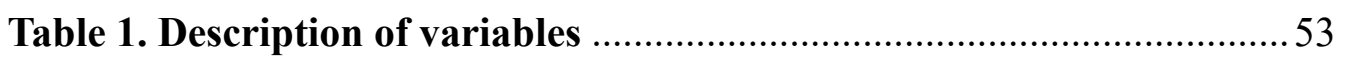

Table 2. Capital gains lock-in and discretionary accruals.........................5 54

Table 3. Capital gains lock-in and accrual quality .....................................5 55

Table 4. Capital gains lock-in and special items.....................................56 
Table 5. Capital gains lock-in and real earnings management 57

Table 6. Capital gains lock-in and restatement .58

Table 7. Capital gains lock-in, discretionary accruals, and the capital gains tax rate .59

Table 8: Mechanism of capital gains lock-in effect 60 


\section{The Capital Gains Lock-in Effect on Earnings Quality}

\section{Summary}

The taxation of realized capital gains creates a lock-in effect. I examine how the capital gains lock-in of mutual funds affects their portfolio firms' earnings quality. I hypothesize and find that unrealized capital gains of mutual funds are positively associated with the earnings quality of their portfolio firms. Consistent with taxinduced lock-in, the effect of unrealized capital gains is more pronounced for taxsensitive mutual funds than for tax-insensitive mutual funds. My findings are robust to five alternative categories of earnings quality measures. Moreover, the positive effect of capital gains lock-in on earning quality is stronger during periods of high capital gain tax and when the mutual fund holdings are highly concentrated. In sum, my findings suggest that locked-in mutual funds improve their portfolio firms' earnings quality through more monitoring.

Keywords: Earnings Quality, Capital Gains Lock-in, Mutual Funds JEL Classification: M41; G23 


\section{Introduction}

Mutual funds that have accumulated capital gains are reluctant to sell securities that have appreciated in value, because realizing such capital gains incurs substantial tax payments. By deferring the realization of gains, mutual fund managers effectively lower the present value of the capital gain tax that fund investors must pay. Thus, unrealized capital gains incentivize mutual funds to hold such securities for longerterm, giving rise to a lock-in effect. This effect is commonly referred to as the capital gains lock-in effect, and numerous papers in the finance literature provide evidence in support of it. ${ }^{1}$ In this study, I examine how the capital gains lock-in effect shapes firms' earnings quality. ${ }^{2}$ Given the drastic growth in the fraction of total U.S. equity held by open-end mutual funds (French, 2008), it is all the more important to understand whether and how this increasingly influential class of investors affects the accounting practice of their portfolio companies.

I hypothesize that the presence of mutual funds being locked-in for tax reason is associated with better earnings quality. These funds lack opportunities for quick exits, forcing them to consider the portfolio firm's long-term prospects. This likely results in more monitoring and higher earnings quality. If the tax-related rationale underlying my hypothesis is true, I further expect the effect on earnings quality is more pronounced for tax-sensitive mutual funds, because these funds have stronger motivation to minimize clients' tax liability.

\footnotetext{
1 See, for example, Feldstein, Slemrod, and Yitzhaki (1980), Landsman and Shackelford (1995), Reese (1998), Klein (2001), Huddart and Narayanan (2002), Ayers, Lefanowicz, and Robinson (2003), Blouin, Raedy, and Shackelford (2003), Ivković, Poterba, and Weisbenner (2005), Jin (2006), Ayers, Li, and Robinson (2008), Dai, Maydew, Shackelford, and Zhang (2008), Ivković and Weisbenner (2009), Sialm and Starks (2012), Li, Lin, and Robinson (2016), and Blouin, Bushee, and Sikes (2017).

2 For expositional simplicity, in this study, the term "capital gain" is used to refer to the percentage change in the share price since the time of purchase, which can be either a gain or a loss. Relative to (tax-sensitive) mutual funds with unrealized capital losses, (tax-sensitive) mutual funds with unrealized capital gains are more likely to be locked-in and expend greater monitoring effort.
} 
However, my hypothesis is not obvious. First, there exist forces that work against the capital gains lock-in effect, such as the disposition effect, the rebalancing effect, and investors' belief in mean-reverting asset prices. Second, managers may manipulate earnings to increase shareholder value, implying that mutual funds lockedin for tax reasons may not discourage earnings management. Third, since locked-in mutual funds face higher exit cost, their request to improve earnings quality may be ignored by the management, because funds' threat of exit is no longer credible.

I test my hypothesis using U.S. data for the period from 1997 to 2008. For each firm-quarter, I calculate the dollar value of capital gains held by mutual funds normalized by the company's beginning of quarter market capitalization. I measure earnings quality using a number of proxies, including performance matched discretionary accruals (Kothari, Leone, \& Wasley, 2005), accruals quality derived using the modified Dechow and Dichev (2002) approach (McNichols, 2002), special items, real activities manipulation (Cohen, Dey, \& Lys, 2008; Roychowdhury, 2006), and accounting restatements. Using these measures of earnings quality, I consistently find support for my hypothesis: mutual funds' unrealized capital gains have a positive effect on their portfolio firms' earnings quality. This effect is economically meaningful. For example, a one standard deviation increase in unrealized capital gains is associated with a $6.04 \%$ decrease in absolute discretionary accruals (evaluated at the sample mean).

I further split my capital gains overhang measure based on the tax sensitivity of the mutual fund investors. I deem mutual funds with a low (high) proportion of assets held by retirement funds as tax-sensitive (tax-insensitive) funds. Consistent with the tax consideration, the positive relation between earnings quality and unrealized capital gains is more pronounced for tax-sensitive mutual funds, than for tax-insensitive 
mutual funds.

There exists a reverse causality explanation. That is, my results may be due to that higher earnings quality leads to larger unrealized capital gains. I note that this reverse causality is unlikely to hold for at least three reasons. First, prior findings generally show that earnings quality is negatively related to the costs of equity and expected returns. ${ }^{3}$ Therefore, higher earnings quality is expected to reduce unrealized capital gains, which is opposite to what I have documented. Second, I use the unrealized capital gains measured as of the beginning of the quarter to explain the earnings quality measured as of the end of the quarter. Third, the reverse causality problem also means that mutual funds with high tax sensitivity and long holding periods choose companies with better accounting quality. By including firm fixed effects, I remove the invariant firm characteristics, so the reverse causality story can no longer be about the companies' stable characteristics over time but has to be about time-variation. With firm fixed effects the alternative story would have to be that mutual funds with high tax sensitivity and long holding periods accurately predict which companies will change their earnings quality in the future, buy shares based on this prediction of improved earnings quality, and hold until the earnings quality improves. This alternative story would be consistent with the pattern that I observe, but it is not at all obvious why it would occur or how the mutual funds are sufficiently skilled at predicting time-variation in earnings quality.

A potential concern of my analysis is that tax-sensitive mutual funds and taxinsensitive mutual funds may differ on dimensions other than their tax sensitivity, and

\footnotetext{
3 See, for example, Dechow, Sloan, and Sweeney (1996), Francis, LaFond, Olsson, and Schipper (2004), Hribar and Jenkins (2004), Aboody, Hughes, and Liu (2005), Francis, LaFond, Olsson, and Schipper (2005), D. Kim and Qi (2010), Kravet and Shevlin (2010), Lara, Osma, and Penalva (2011), Bhattacharya, Ecker, Olsson, and Schipper (2012), Barth, Konchitchki, and Landsman (2013), J.-B. Kim and Sohn (2013).
} 
that these differences, rather than the extent of capital gains lock-in, are responsible for my findings. To address this possibility, I examine whether the effect of capital gains lock-in on earnings quality varies with the capital gains tax rate. For any given amount of unrealized taxable capital gains, an increase in capital gains tax should increase the extent of lock-in because the cost of realizing the gain increases. Consistent with the tax-induced lock-in effect, the effect of unrealized capital gains is larger for taxsensitive mutual funds when the tax rate is higher.

One remaining concern is that my results based on the tax rate change are also consistent with the possibility that other fund characteristics change with the capital gains tax rate just by coincidence. To address this issue, I utilize the tax cut induced by the Jobs and Growth Tax Relief Reconciliation Act of 2003 and examine a 3-year window and a 5-year window surrounding the 2003 tax rate change. The shorter windows make it less likely that other time-series changes affect the results. Consistent with tax motivations, the relation between earnings quality and the unrealized gains of tax-sensitive mutual funds decreases significantly from one year (or two years) before to one year (or two years) after the tax cut year. However, no similar change is observed for tax-insensitive mutual funds. The comparison of the coefficient estimates shows that the tax-cut-induced decrease in the effect of unrealized capital gains is significantly more pronounced for tax-sensitive mutual funds, thus providing further evidence for the tax explanation of my research findings.

If indeed the effect I document is related to mutual fund monitoring, I expect that the effect is more pronounced for mutual funds with concentrated holdings. First, mutual funds with concentrated holdings have more incentive to monitor. Shleifer and Vishny (1986) argue that concentrated ownership provides a partial solution to the free rider problem of monitoring. Concentrated shareholders with a large stake are 
motivated to monitor because the monitoring benefits accrued to them are higher than the monitoring costs. Second, concentrated ownership enables mutual funds to have more ability to influence firm managers. Employing the Herfindahl-Hirschman Index as a measure of ownership concentration at the portfolio firm level, I find that the effect of unrealized capital gains is most significant for tax-sensitive mutual funds when holdings are highly concentrated among only a small number of funds. In addition, the capital gains lock-in effect is significant when mutual fund holdings are highly concentrated but is not when the concentration level is low. Finally, the lock-in effect is more pronounced when the concentration level is higher.

There are several possible channels that locked-in mutual funds can improve the earnings quality of their portfolio firms. First, mutual funds can communicate their concerns over earnings quality directly with the firm management behind the scenes or they can engage in private discussions with members of the board of directors outside of management's presence. These engagements are expected to be more intense for locked-in funds since they are incentivized to hold the stocks for long term due to tax reason (McCahery, Sautner, \& Starks, 2016). ${ }^{4}$ Second, mutual fund managers may rely on sell-side analysts to push the management on earnings quality issues on their behalf (Brown, Call, Clement, \& Sharp, 2018). Finally, locked-in mutual funds with a long-term focus are unlikely to trade on earnings news or pressure the management to manipulate earnings. In addition, locked-in funds would evaluate firm management based on long-run target and thus disincentivize the managers to engage in earnings management for short-term reasons.

My research focuses on the mutual funds. The reason is largely related to the

\footnotetext{
4 In Table III of McCahery et al. (2016), the authors show that voice intensity increases with investor horizon. In addition, the engagement is significantly more intense for mutual funds than "other" institutional investor type.
} 
data availability. First, to construct the unrealized capital gains measure, I need the holding data and the U.S. Securities and Exchange Commission requires mutual funds to report complete lists of their holdings on a quarterly basis. Second, to identify the tax-induced lock-in effect, I requires the availability of Pensions \& Investments data from which I get the information about the tax status of mutual funds' investors. Unfortunately, these data are unavailable for other institutions. However, it is important to emphasize that the capital gains lock-in effect exists not only for taxsensitive mutual funds, but also for other types of taxable accounts; and that the conclusion of my research may naturally be applied to other types of investors.

My paper relates to several strands of literature. First, it relates to the literature on capital gains lock-in effect. Although a number of asset pricing studies have examined this topic, ${ }^{5}$ only a few studies examine the impact of capital gains lock-in on corporate behavior. Dimmock, Gerken, Ivković, and Weisbenner (2018) investigate the relation between the capital gains lock-in effect and mutual funds' willingness to oppose management on contentious voting proposals. Sikes (2017) examines the capital gains lock-in effect on firms' share repurchases. To my knowledge, my study is the first to assess how capital gains lock-in affects firms' accounting practices.

Dimmock et al. (2018) show that locked-in mutual funds are more likely to vote against the management in proxy voting. Proxy voting and improving portfolio firms' earnings quality are, in my opinion, two separate decisions, which involve different cost-benefit analyses. Monitoring financial reporting requires specialized accounting knowledge. Furthermore, there is substantial managerial discretion over financial reporting (e.g., discretionary accruals and special items) and managers can

\footnotetext{
${ }^{5}$ See, for example, papers enumerated in footnote 1.
} 
easily justify their financial accounting choices. It's unclear at all whether a mutual fund which votes against the management is equally likely to keep an eye out for accounting issues. Finally, for mutual fund voting, there are advisory firms that sell voting advice to institutional investors and many mutual funds almost entirely outsource voting decisions to proxy advisors. ${ }^{6}$ The voting outcome therefore may be attributed to advisory firms rather than mutual funds' own decision making.

Second, my paper contributes to a voluminous literature on tax research, especially the literature on tax and earnings management. One line of this research examines whether and how tax avoidance affects earnings quality, and finds mixed results. ${ }^{7}$ Another line of research is related to earnings management through the tax accounts. All these studies are about corporate tax and earnings management, while I focus on an entirely new setting by investigating how capital gains taxation of mutual fund investors influences firms' accounting choices.

Third, my study is closely related to the literature on institutional investors and earnings quality. This line of literature focuses on the aggregate proportion of shares held by institutional investors. ${ }^{8}$ I examine the issue from the fund level, offering a more granular view of how institutional ownership influences firms' accounting quality. By doing so, I am able to show that the tax status of individual funds has an impact on firms' accounting quality.

Finally, my research is related to the corporate governance literature on voice

\footnotetext{
${ }^{6}$ Institutional Shareholder Services and Glass Lewis are two main players.

7 For positive association between tax aggressiveness/avoidance and earnings quality, see, for example, Erickson, Hanlon, and Maydew (2004), Lennox, Lisowsky, and Pittman (2013), and Blaylock, Gaertner, and Shevlin (2015). For negative association, see, for example, Frank, Lynch, and Rego (2009), J.-B. Kim, Li, and Zhang (2011), Hanlon, Krishnan, and Mills (2012), Donohoe and Robert Knechel (2014), and Balakrishnan, Blouin, and Guay (2018).

8 See, for example, Bushee (1998), Bushee (2001), Koh (2007), Ramalingegowda and Yu (2012), and Harford, Kecskes, and Mansi (2017).
} 
versus exit. There is a theoretical debate in finance on whether locked-in investors are better monitors, or whether the credible threat of exit results in better governance. ${ }^{9}$ My results support that locked-in mutual funds influence managers through monitoring, which is consistent with the voice papers.

In what follows, Section 2 reviews the relevant literature; Section 3 develops the hypothesis; Section 4 describes the data and variables; Section 5 presents the main results; Section 6 addresses the tax motivation; Section 7 discusses the mechanism of the capital gains lock-in effect, and Section 8 concludes.

\section{Literature review}

In order to establish the link between my study and the current literature, in this section, I review the prior research on (1) capital gains lock-in effect, (2) tax and earnings management, and (3) institutional investors and earnings management.

\subsection{Capital gains lock-in effect}

Prior asset pricing studies in the finance literature on the capital gains lock-in effect generally look at the effect of lock-in on asset price and trading decision. An early study by Feldstein et al. (1980) shows that high capital gains tax reduces the selling of stock if such sales trigger the realization of net capital gains. Landsman and Shackelford (1995) provide evidence that investors demand higher selling price when the tax basis of the stock sold is lower. Given that short term capital gains are taxed at higher rate than long-term capital gains, Reese (1998) show that investors delay the sale of assets that are appreciated in value and accelerate the sale of depreciated assets. To explain the capital market anomaly, Klein (2001) documents that long-term return

\footnotetext{
9 See, for example, Coffee (1991), Kahn and Winton (1998), Maug (1998), Amihud (2002), Admati and Pfleiderer (2009), Yermack (2010), Edmans (2014), Fos and Kahn (2014), and Levit (2018).
} 
reversal can be due to accumulated capital gains. As to the mutual fund trading decision, Huddart and Narayanan (2002) find that growth funds are reluctant to sell securities as the unrealized gain accrues, but this pattern will not occur for balanced and income mutual funds, and tax-exempt institutions. In a merger and acquisition setting, Ayers et al. (2003) document that capital gains taxes for individual investors are positively related to the taxable acquisition premiums. As to individual investors, Blouin et al. (2003) find that they defer sales of appreciated stock to realize long-term gains which are more tax-favored. Ivković et al. (2005) provide evidence of tax-loss harvesting and capital gains lock-in effect in taxable accounts. Jin (2006) show that the selling by institutions with largely taxable investors is negatively associated with accrued capital gains. He also documents higher abnormal returns around the threeday earnings announcement window for stocks held by tax-sensitive investors. Using the Taxpayer Relief Act of 1997 as the empirical setting, Ayers et al. (2008) provide evidence for the capital gains lock-in effect on the effective day and Dai et al. (2008) document the lock-in effect in the week after the effective day. Ivković and Weisbenner (2009) find that individual investors are reluctant to sell appreciated mutual funds and are willing to sell funds with loss. Sialm and Starks (2012) provides evidence for the mutual fund tax clienteles such that mutual funds with largely taxable investors select investment strategies that incur lower tax liabilities. Consistent with lock-in, Li et al. (2016) show that the underpricing of initial public offering is positively associated with the difference between short-term and long-term capital gains tax rates. Related to the methodological issue, Blouin et al. (2017) develop a new measure of tax-sensitive institutional ownership and show that their measure provides more power than others.

Although there is a large literature of the asset pricing studies, to my 
knowledge, only two corporate finance papers investigate the implication of capital gains lock-in. Sikes (2017) shows that capital gains lock-in leads to less stock repurchase because of reduced supply of shares and higher stock price. Dimmock et al. (2018) find that, for mutual funds, capital gains lock-in results in higher likelihood of opposing management on contentious votes. In addition, the authors show that capital gains lock-in leads to higher likelihood of management losing a contentious vote, fewer contentious proposals on the meeting agenda, more positive stock market reaction in the period around the ISS announcement opposing management, and higher future net fund flows.

Given that the capital gains lock-in effect is well established in the asset pricing literature in finance, relatively few studies examine its implication on corporate behavior. I believe it is natural to extend the idea of capital gains lock-in to accounting research, and as far as I know, my paper is the first accounting research investigating the consequences of capital gains lock-in on firms' accounting practices. My study is related to Dimmock et al. (2018) to some extent, but as I discussed earlier in the introduction, their conclusion may not necessarily be generalized to my research. In addition, Dimmock et al. (2018) do not specifically look at the real consequences of capital gains lock-in on managerial behavior.

\subsection{Tax and earnings management}

The current literature on tax and earnings management generally focus on two areas. The first line of research examines whether and how tax avoidance is related to earnings quality. The results are mixed. On the one hand, Erickson et al. (2004) find that some firms include fraudulently inflated earnings on their tax returns and are willing to pay more taxes to avoid being detected, suggesting a negative association between earnings management and tax avoidance. Lennox et al. (2013) show that tax- 
aggressive firms are less apt to commit accounting fraud in the U.S. Blaylock et al. (2015) find that higher book-tax conformity is associated with more earnings management in an international setting.

On the other hand, Frank et al. (2009) document a positive relation between financial and tax reporting aggressiveness. Their finding suggests that, under the current requirement of financial reporting standards and tax law, firms can manipulate earnings upward and taxable income downward simultaneously. J.-B. Kim et al. (2011) find that tax planning is positively associated with stock price crash risk, suggesting that complicated tax avoidance activities create an opportunity for managers to manufacture earnings and hoard bad news. Hanlon et al. (2012) document a positive association between book-tax differences and audit fees, which is consistent with higher book-tax conformity reflecting higher earnings quality that is associated with lower assessed risk and audit effort. Donohoe and Robert Knechel (2014) show that tax aggressiveness is a component of audit risk that is separately priced by auditors. Balakrishnan, Blouin, and Guay (2018) find that tax aggressiveness is associated with lower corporate transparency because complex tax avoidance activities increase the financial complexity of the firm.

The second line of research investigates earnings management through the tax accounts. As reviewed by Hanlon and Heitzman (2010), a number of studies examine whether and how earnings are managed through (at least) three tax accounts: the valuation allowance, the tax contingency reserve, and the amount of foreign earnings designated as permanently reinvested. Graham, Raedy, and Shackelford (2012) also conduct a comprehensive review of the research on earnings management via the valuation allowance, the tax contingency account, and discretion in reporting the U.S. 
tax expense on foreign profits.

Finally, several studies examine managerial earnings manipulation in response to corporate tax rate changes. Among others, Scholes, Wilson, and Wolfson (1992) find that sales recognition is deferred and that expense recognition is accelerated until tax rates decreased in 1986. Similarly, Guenther (1994) reports lower current accruals for large firms for the year before the 1986 tax rate cut. Devlin (2015) shows that firm managers manipulate earnings to a greater extent when capital gains tax rates fall. Doing so would maximize their personal wealth to the amount of company income they manage, as a lower level of tax would be paid on each dollar received from selling the stock.

While all these studies are related to the corporate tax and earnings management, I establish an entirely new area within the literature on tax and earnings management by looking at whether and how the taxation imposed on firm investors will influence firm's earnings quality.

\subsection{Institutional investors and earnings management}

Prior research has investigated whether and how institutional ownership will affect earnings quality. For example, Bushee (1998) finds that managers are less likely to cut research and development (R\&D) expenses to reverse earnings decrease when institutional ownership is high, but they tend to do so if institutional investors have high portfolio turnover and engage in momentum trading. Bange and De Bondt (1998) find that managers change $R \& D$ spending to reduce the difference between reported earnings and analyst earnings forecasts and that less gap is closed when institutional ownership is higher. Bushee (1998) demonstrates that transient institutional investors exhibit strong preferences for near-term value. Chung, Firth, and Kim (2002) find that, consistent with the monitoring story, large institutional investors reduce accruals-based 
earnings management. Velury and Jenkins (2006) document a positive association between institutional ownership and earnings quality, but concentrated institutional ownership tends to reduce earnings quality. Koh (2007) presents evidence that less accruals-based earnings management used to meet or beat earnings benchmarks occurs in firms with longer-term institutional ownership. Burns, Kedia, and Lipson (2010) find that the likelihood and severity of misreporting is higher in the presence of shorter-term institutional ownership and that this effect is offset by concentrated ownership. Guthrie and Sokolowsky (2010) document that firm boosts income around seasoned equity offerings when there are large outsider blockholdings.

Ramalingegowda and Yu (2012) show that the ownership by monitoring institutions that are independent with long-term and concentrated holdings is positively associated with accounting conservatism. Using survey methodology, McCahery et al. (2016) show that long-term investors intervene more intensively than short-term investors. In general, the conclusion in this literature is that long-term institutional investors monitor the firm and deter both real and accrual-based earnings management.

Some recent studies use the annual reconstitution of the Russell 1000 and Russell 2000 Indexes as a source of exogenous variation in institutional ownership to study the effect of institutional ownership on various firm outcomes. For example, Harford et al. (2017) find that long-term investors strengthen governance and restrain earnings management and financial fraud. Baig, DeLisle, and Zaynutdinova (2018) find that passive ownership is negatively related to earnings management. Similarly, Fang and Cheng (2018) document a positive effect of quasi-indexer ownership on accounting information quality.

Although prior studies suggest that institutional investors, especially those with long-term horizon, engage in monitoring to improve earnings quality; it is not clear at 
all from the literature why some institutions choose to hold their positions for long period. In my study, I identify on such economic reason, namely, the capital gains lock-in by the mutual funds due to tax consideration. The capital gains lock-in effect documented in my study is not specific to mutual funds and can be naturally extended to other investor types. In addition, it is important to emphasize that the lock-in effect which is the focus of my study is distinct from the ownership effect. Given that mutual funds do not change their positions, their ownership keeps constant even if they accumulate capital gains or losses as stock prices fluctuate. My empirical results show that the capital gains lock-in effect is incremental to the effects of mutual fund ownership and overall institutional ownership.

\section{Hypothesis development}

Mutual funds with unrealized capital gains face significant exit costs, because selling shares will trigger capital gains for the funds' investors which in turn will reduce after-tax returns and flows into the fund (e.g., Bergstresser and Poterba (2002)). This creates a disincentive for the fund to sell the stock, locking the fund into a position.

I argue that locked-in mutual funds will discourage earnings management for several reasons. First, empirical studies have documented that managers are incentivized to manage earnings upwards to increase their compensation, establish their reputation, and avoid being fired. ${ }^{10}$ While artificially inflated accounting profits may lead to over-pricing and give existing investors an opportunity to cash out, this type of opportunity is unavailable to capital-gain locked-in mutual funds since they face high exit costs. Furthermore, earnings manipulations are essentially reallocations

\footnotetext{
10 See, for example, Watts and Zimmerman (1978), Healy (1985), Murphy and Zimmerman (1993), Ball (2001), Graham, Harvey, and Rajgopal (2005), and Lafond and Roychowdhury (2008).
} 
of earnings to different time periods. For mutual funds being locked-in for tax reasons, this type of reallocation does not yield any benefit, since the accumulated earnings is the same over the long-term.

Second, prior findings generally support that the costs of equity and of debt are higher when earnings quality is lower. ${ }^{11}$ An increase in weighted average cost of capital reduces firm value. Mutual fund managers have financial incentives to maximize the returns of portfolio firms to generate additional fees and attract new capital inflows. This creates an incentive for locked-in mutual funds to monitor firm managers and reduce the cost of capital by limiting managers' ability to distort earnings information.

Third, investors react negatively to news of restatements. Palmrose, Richardson, and Scholz (2004) document an average market-adjusted return of $-9.2 \%$ over a two-day restatement announcement window from day zero to day one. The average abnormal return is $-20 \%$ for restatements associated with fraud. Karpoff, Koester, Lee, and Martin (2017) show that the mean cumulated market-adjusted return for the restatement announcements in the Audit Analytics database that are associated with 13(b) Securities and Exchange Commission (SEC) enforcement activity is $-5.1 \%$. The mean cumulated abnormal return summing over all event dates in each Audit Analytics-identified case of misconduct is $-33.3 \%$. To avoid the negative returns associated with accounting restatements, locked-in mutual funds would demand high earnings quality through their monitoring. Collectively, these factors suggest that capital-gain locked-in mutual funds benefit from and will demand high quality earnings.

\footnotetext{
${ }^{11}$ For effect of earnings quality on cost of equity, see, for example, paper listed in footnote 3. For effect of earnings quality on cost of debt, see, for example, Beatty, Ramesh, and Weber (2002), Anderson, Mansi, and Reeb (2004), Francis et al. (2005), Graham, Li, and Qiu (2008), Wittenberg-Moerman (2008), Ge and Kim (2014).
} 
I therefore have the following hypothesis about the mutual funds' unrealized capital gains and the earnings quality of their portfolio companies:

H1: The amount of unrealized capital gains of mutual funds is positively associated with the earnings quality of their portfolio firms.

I further propose that the effect of unrealized capital gains should depend on the tax status of the funds' investors. For tax-sensitive mutual funds, given an unrealized capital gain on a stock, unwinding the position imposes tax costs on the funds' investors. Ignoring tax efficiency is costly for mutual fund managers because funds that offer higher after-tax return attract greater inflows (Bergstresser \& Poterba, 2002). In addition, Sialm and Zhang (2018) provide evidence that investors are significantly better off if they invest in funds with greater tax efficiency. However, unloading a position will incur little capital gains tax for tax-insensitive mutual funds. Therefore, tax costs motivate mutual funds with largely taxable clienteles to delay selling stocks for which they have unrealized gains, relative to funds with largely taxexempt clienteles. As a sharper test of my hypothesis, I expect that the effect of unrealized capital gains on earnings quality will be stronger for tax-sensitive mutual funds than for tax-insensitive mutual funds.

My hypothesis is not without tension. First, mutual funds with unrealized capital gains, especially passively managed index funds and quasi-indexers, need to sell shares for rebalancing purpose. In addition, prior studies widely document that investors tend to exhibit disposition effect. ${ }^{12}$ Moreover, if investors, either rationally or irrationally, believe that asset prices will revert to mean in the long run, they should sell (purchase) stocks which have appreciated (depreciated) in value. Therefore, if the combination of (1) the need to rebalance, (2) the disposition effect, and (3) investors'

\footnotetext{
12 See, for example, Kahneman and Tversky (1979), Shefrin and Statman (1985), Odean (1998), Ivković et al. (2005), Frazzini (2006), and Cici (2012).
} 
belief in mean-reverting asset prices is stronger than the capital gains lock-in effect in my empirical setting, I should find that investors are more likely to exit after capital appreciation. Second, less earnings manipulation does not necessarily maximize shareholder value. Kirschenheiter and Melumad (2002) show that both earnings smoothing and the big bath phenomena are part of an equilibrium reporting strategy that may maximize firm value. As another example, if firms manage earnings to avoid violating debt covenants and paying more in interest, earnings management could increase shareholder wealth (Watts \& Zimmerman, 1978). In these cases, funds with unrealized capital gains may encourage earnings management. Third, because mutual funds with unrealized capital gains are locked in, their threat of exit will not be taken seriously by the managers of portfolio firms. In sum, the management is likely to brush aside those mutual funds' requests on earnings quality. This will predict the opposite of my hypothesis. Therefore, the effect of unrealized capital gains on earnings quality is an empirical question.

\section{Data and variables}

\subsection{Main sample}

To construct the main dataset for the empirical analysis, I start with the entire Compustat quarterly sample from 1997 to $2008 .^{13}$ The sample period is selected based on the availability of the Pensions \& Investments data from which I get the information about the tax status of mutual funds' investors. In annual surveys conducted by Pensions \& Investments, mutual fund families are asked to report the proportion of assets held in tax deferred plans for each of the family's 12 largest funds.

\footnotetext{
13 It would be natural to expect that the results in my study will apply in the current U.S. tax regime with the size of capital gains lock-in effect depending on the magnitude of capital gains tax rate.
} 
In particular, the survey results provide information on the total assets under management in defined contribution accounts as of the end of the year prior to the survey date for the mutual funds most used by defined contribution plans in broad investment categories (i.e., domestic equity funds, domestic fixed income funds, international equity funds, balanced funds, and money market funds). ${ }^{14}$ I only include domestic equity funds because they are the most commonly used mutual funds in defined contribution pension plans over my sample period. Doing so also allows me to abstract from changes in asset classes across the plans. My sample is limited to December year-end firms to ensure that fiscal firm-quarters are aligned in time (Freeman \& Tse, 1992; Thomas \& Zhang, 2008). Observations with non-positive total assets are dropped. I also drop firms from utilities and financial service industries (2digit SIC codes of 49 and 60-67). I require all variables in the regression model to be available.

\subsection{Description of the dependent variables}

To evaluate the impact of capital gains lock-in on earnings quality, I examine five earnings quality measures which have been widely studied in the literature.

\subsubsection{Performance matched discretionary accruals}

My main dependent variable is the absolute value of performance matched discretionary accruals scaled by average total assets. It is based on a quarterly version of the model developed by Kothari et al. (2005). In particular, I calculate performance matched discretionary accruals as the residual from the following regression with firm subscripts omitted.

\footnotetext{
14 I thank David Klein from Pensions \& Investments for providing me the data. It is available for purchase at http://www.pionline.com/data-store. Additional information about the survey can be obtained at http://www.pionline.com. The same data source has been used by previous studies, such as Sialm and Starks (2012), Sialm, Starks, and Zhang (2015), and Dimmock et al. (2018).
} 


$$
\begin{aligned}
T A_{q} / A v g A T_{q}= & \beta_{0}+\beta_{1}\left(1 / A v g A T_{q}\right)+\beta_{2}\left[\left(\Delta \text { Sale }_{q}-\Delta R E C_{q}\right) / A v g A T_{q}\right] \\
& +\beta_{3}\left(P P E_{q} / A v g A T_{q}\right)+\beta_{4}\left(\text { Earning }_{q-1} / A v g A T_{q-1}\right)+\varepsilon_{q} .
\end{aligned}
$$

In the equation above,

represents the current quarter.

$T A$

is the total accruals for the quarter. $T A$ is computed as earnings before extraordinary items (quarterly Compustat data item $I B Q$ ) minus cash flow from operations $(O A N C F Q)$, adjusted for extraordinary items and discontinued items $(X I D O C Q)$. In the quarterly Compustat database, the value of quarterly cash flow from operations $(O A N C F Q)$ is not provided. Only the year-to-date cash flow from operations (OANCFY) is available. Therefore, except for the first fiscal quarter, in which $O A N C F Q$ is the same as $O A N C F Y$ by construct, in order to obtain $O A N C F Q$ for the current quarter, $O A N C F Y$ for the previous quarter is subtracted from $O A N C F Y$ for the current quarter. The amount of extraordinary items and discontinued operations on the quarterly cash flow statement $(X I D O C Q)$ is obtained using a similar approach.

$\operatorname{Avg} A T \quad$ is calculated as the average of total assets at the end of the current quarter and previous quarter.

$\triangle S A L E \quad$ is calculated as the difference between sales in the current quarter and sales in the previous quarter.

$\triangle R E C \quad$ is calculated as the difference between accounts receivable at the end of the current quarter and accounts receivable at the end of the previous quarter.

PPE is the net amount of property, plant, and equipment (PPE) at the end of 
the quarter. ${ }^{15}$

EARNINGS is the income before extraordinary items.

I estimate this model for each industry-quarter combination, with industry defined by the first two digits of the SIC code, and I require at least 20 observations in each industry-quarter. All variables used to estimate model (1) are winsorized at the $1^{\text {st }}$ and $99^{\text {th }}$ percentiles. The absolute values of error terms, $D A$, is my first measure of earnings quality. A larger value of $D A$ implies more earnings management and lower earnings quality.

Recent studies in the accounting literature posit that there are measurement error problems embedded in the discretionary accruals measures. Since my main inference with regard to the capital gains lock-in effect is based on the difference between the effect for tax-sensitive mutual funds and the effect for tax-insensitive mutual funds, I do not expect measurement error problems will introduce any systematic bias. However, to address this concern, I employ four other earnings quality measures to validate the main result.

\subsubsection{Accruals quality using McNichols (2002) modification of Dechow and Dichev} (2002)

Following McNichols (2002), my second measure of earnings quality is based on a quarterly version of the modified Dechow and Dichev (2002) model. The key idea is to model the extent to which current accruals map into previous, current, and future cash flow realizations, while controlling for the change in sales revenue and PPE. I calculate the accruals quality measure, $D D$, as the absolute value of the residual

\footnotetext{
15 Following prior research (Bratten, Payne, \& Thomas, 2016), I use net PPE instead of gross PPE in model (1) because the latter has many missing observations on the quarterly tape. The caveat of switching to net PPE is the potential effect of managerial discretion on depreciation and amortization being attributed to non-discretionary accruals. However, in my sample, net PPE and gross PPE exhibit a very high correlation of 0.9707 .
} 
from the following regression, multiplied by negative one. Firm subscripts are omitted. ${ }^{16}$

$$
\begin{aligned}
& T A_{q} / A v g A T_{q}=\beta_{0}+\beta_{1}\left(O A N C F Q_{q-1} / A v g A T_{q-1}\right)+\beta_{2}\left(O A N C F Q_{q} / A v g A T_{q}\right) \\
& +\beta_{3}\left(O A N C F Q_{q+1} / A v g A T_{q+1}\right)+\beta_{4}\left(\Delta \text { Sale }_{q} / A v g A T_{q}\right) \\
& +\beta_{5}\left(P P E_{q} / A v g A T_{q}\right)+\varepsilon_{q}
\end{aligned}
$$

All the variables are defined in model (1). I estimate this regression for each industry-quarter combination, requiring at least 20 observations to estimate each industry-quarter regression. All variables used to estimate the accruals "errors" are winsorized at the $1^{\text {st }}$ and $99^{\text {th }}$ percentiles for each industry-quarter. A larger value of $D D$ implies higher earnings quality.

\subsubsection{Special items}

My third measure of earnings quality is related to special items. Unlike the first two measures, this one is model-free and thus is not subject to the measurement error problem. As discussed by Dechow, Ge, and Schrand (2010), prior studies generally document that special items are accrual adjustments that reduce earnings persistence and accruals persistence, suggesting that greater special items are associated with lower earnings quality. For equity valuation purpose, special items are not helpful for predicting future earnings, since they are transitory by nature. Therefore, my third dependent variable is $A B S S P I$, which is the absolute value of the special items (SPIQ) scaled by total assets $(A T Q)$. A larger value of $A B S S P I$ indicates lower earnings quality.

\footnotetext{
${ }_{16}$ Using current total accruals scaled by average total assets as the dependent variable in model (2) will not change my inference in Section 4.2.2.
} 


\subsubsection{Real earnings management}

My next set of dependent variables are related to real earnings management. I build on prior studies to develop proxies for real earnings management (Cohen et al., 2008; Roychowdhury, 2006).

First, I examine abnormal operating cash flows. In a given quarter. firms may choose to generate additional sales by offering price discounts or more lenient credit terms to their customers. Such temporary discounts and lenient credit terms will increase sales volumes in the current period, but will disappear once the firm reverts to old higher prices. The additional sales will boost current period earnings, assuming positive margins. However, both price discounts and more lenient credit terms will reduce current operating cash flows if the suppliers do not offer similar discounts on firm inputs. I run the following cross-sectional regression for each industry and quarter to estimate normal operating cash flows. Firm subscripts are omitted.

$$
\begin{aligned}
& C F O_{q} / A T Q_{q-1}=\beta_{0}+\beta_{1}\left(1 / A T Q_{q-1}\right)+ \\
& \beta_{2}\left(S A L E_{q} / A T Q_{q-1}\right) \\
& \quad+\left(\Delta S A L E_{q} / A T Q_{q-1}\right)+\varepsilon_{q} .
\end{aligned}
$$

In the equation above,

$q \quad$ represents the current quarter.

$\mathrm{CFO}$ is defined as cash flow from operations $(O A N C F Q)$ adjusted for extraordinary items and discontinued items $(X I D O C Q)$.

ATQ represents total assets $(A T Q)$.

SALE represents sales.

$\triangle S A L E \quad$ is calculated as the difference between sales in the current quarter and sales in the previous quarter.

Abnormal $C F O$ is the error terms obtained from model (3). Firms that manage 
earnings upward via sales manipulation are likely to have unusually low cash flow from operations relative to total assets. Therefore, I multiply abnormal $C F O$ by negative one to get $A B C F O$, so that the higher the value, the greater the likelihood that the firm engages in real earnings management to increase current period earnings.

Second, I investigate overproduction as a tool to manipulate earnings. Firms may lower cost of goods sold by producing more goods than necessary. This spreads fixed costs over a larger number of units, lowering fixed costs per unit. As long as the reduction in fixed costs per unit is not offset by any increase in marginal cost per unit, total cost per unit declines. However, for those over-produced items that cannot be sold in the current period, the firm will incur other expenses, such as storage costs, resulting in higher quarterly production costs relative to sales. To estimate the normal level of production costs, I run the following cross-sectional regression for each industry and quarter with firm subscripts being omitted.

$$
\begin{aligned}
\operatorname{PROD}_{q} / A T Q_{q-1}= & \beta_{0}+\beta_{1}\left(1 / A T Q_{q-1}\right)+\beta_{2}\left(S A L E_{q} / A T Q_{q-1}\right) \\
& +\beta_{3}\left(\Delta S A L E_{q} / A T Q_{q-1}\right)+\beta_{4}\left(\Delta S A L E_{q-1} / A T Q_{q-1}\right)+\varepsilon_{q}
\end{aligned}
$$

In the equation above,

$q$ represents the current quarter.

$P R O D \quad$ is production costs which are defined as the sum of cost of goods sold $(C O G S Q)$ and change in inventory $(I N V T Q)$.

ATQ represents total assets $(A T Q)$.

SALE represents sales.

$\triangle S A L E \quad$ is calculated as the difference between sales in the current quarter and sales in the previous quarter.

Abnormal production costs $(A B P R O D)$ are actual production costs minus the normal level of production costs calculated using the estimated coefficients from the 
equation above. Firms that manage earnings upward are likely to have unusually high production costs. A higher amount of abnormal production costs is indicative of overproduction.

Third, I examine the reduction of discretionary expenditures. Firms may choose to cut discretionary expenses such as (1) advertising, (2) R\&D, and (3) selling, general and administrative (SG\&A), because reducing such expenses will boost current period earnings. It could also lead to higher current period operating cash flows (at the risk of lower future cash flows) if the firm paid for such expenses in cash. Since only R\&D expense $(X R D Q)$ and SG\&A expenses $(X S G A Q)$ data are available on a quarterly basis, I run the following cross-sectional regression for each industry and quarter. Firm subscripts are omitted.

$$
\operatorname{DISX}_{q} / A T Q_{q-1}=\beta_{0}+\beta_{1}\left(1 / A T Q_{q-1}\right)+\beta_{2}\left(S A L E_{q-1} / A T Q_{q-1}\right)+\varepsilon_{q} .
$$

In the equation above,

$q$ represents the current quarter.

DISX represents the discretionary expenditures, defined as the sum of R\&D expenses $(X R D Q)$, and SG\&A expenses $(X S G A Q)$.

ATQ represents total assets $(A T Q)$.

SALE represents sales. Modeling discretionary expenses as a function of current sales creates a mechanical problem if firms manage sales upward to increase reported earnings in a certain year, resulting in significantly lower residuals. To address this issue, I model discretionary expenses as a function of lagged sales.

Abnormal discretionary expenditures are actual discretionary expenditures minus the predicted discretionary expenditures from the regression above. Firms that manage earnings upward are likely to have unusually low discretionary expenditures. 
Therefore, abnormal discretionary expenditures are multiplied by negative one to get $A B D I S X$, so that the value is reflective of the likelihood that the firm cuts $\mathrm{R} \& \mathrm{D}$ expenses and/or SG\&A expenses to boost current period earnings.

In order to capture the total effects of real earnings management, I construct two comprehensive metrics of real earnings management activities. My first measure $R M 1$ is computed as the absolute value of the sum of standardized $A B D I S X$ and standardized $A B P R O D$. The second measure $R M 2$ is computed as the absolute value of the sum of standardized $A B C F O$ and standardized $A B D I S X$. I do not combine $A B P R O D$ and $A B C F O$, because in Roychowdhury (2006), the same activities that lead to abnormally high production costs also lead to abnormally low operating cash flows; thus, adding these two amounts may lead to double counting. Following Cohen et al. (2008), I construct an even more comprehensive measure by computing $R M$ as the absolute value of the sum of the standardized variables, $A B C F O, A B P R O D$, and $A B D I S X$. The amounts of $R M 1, R M 2$, and $R M$ are positively associated with the level of real earnings management activities.

\subsubsection{Restatements}

My last measure of earnings quality is related to accounting restatement. Restatements are external indicators of earnings misstatements. An advantage of this measure of earnings quality is that restatements unambiguously reflect accounting measurement problems, suggesting a low Type I error rate. Another advantage is that I do not need to specify a model to identify misstatements or earnings management. I first use $R E S$ as the dependent variable where $R E S$ represents whether current quarter financial statements are restated later, as identified in the Audit Analytics Restatements file. $R E S$ equals one if the fiscal year-quarter end falls between $R E S \_B E G I N_{-} D A T E$ and RES_END_DATE and zero otherwise. I also examine fraud-related restatements 
by using $R E S \_F R D$, an indicator variable which equals one if the firm has restated current quarter financial statements due to fraud-related reasons and zero otherwise. I define RES_FRD using two variables taken from the Audit Analytics: RES_FRAUD indicates fraud and RES_SEC_INVEST indicates that a filing associated with a restatement disclosed an SEC investigation of the firm. ${ }^{17}$

\subsection{Description of the key explanatory variables}

I identify mutual funds using the CRSP Open-End Survival Bias Free Mutual Fund Database. Following Kacperczyk, Sialm, and Zheng (2006) and for reasons discussed earlier, I limit the sample to actively managed domestic equity funds. I also screen out funds that hold fewer than ten stocks or have less than two million dollars in net assets as of the prior quarter end. I obtain quarterly mutual fund stock holdings from the Thomson-Reuter Mutual Fund Holdings database and match the holdings to the CRSP data using the MFLINKS file on WRDS.

I obtain information on the tax status of the mutual funds' investors from the annual Survey of Defined Contribution Plans produced by Pensions \& Investments. Every year, Pensions \& Investments surveys mutual fund families and obtains the proportion of assets held in tax deferred plans for each of the family's 12 largest funds. ${ }^{18}$ I match the Pensions \& Investments data to the CRSP data using ticker symbols and fund names.

Following Dimmock et al. (2018), I impute the capital gain for each stock held in each mutual fund's portfolio as follows. I infer transactions that occur during the

\footnotetext{
${ }^{17}$ I choose the restatement sample over the Accounting and Auditing Enforcement Release (AAER) sample because prior research identifies several problems with the AAERs, such as small sample sizes, selection issues, and matching problems due to Type II error rate (Dechow et al., 2010). The restatement sample is significantly larger than the AAER sample. In addition, I am able to identify the frauds which are likely to be intentional misstatements using the information provided in the Audit Analytics database.

18 During my sample period, the funds reported in Pension \& Investments control $70 \%$ of the total value of equity funds in the CRSP Mutual Fund database.
} 
quarter by comparing the fund's beginning and end of quarter holdings. For each transaction, I impute the transaction price using daily transaction weighted prices for the quarter (e.g., I take a weighted average of the stock's end-of-day price for each day in the quarter, with the weights determined by the value of transactions occurring on that day). Funds may increase or decrease their holdings in a stock in multiple quarters. Thus, a fund may have multiple tranches of shares, purchased in different quarters and at different costs. To impute the capital gain for a stock holding, I assume that for partial sales of tranches the fund follows the highest-in-first-out method because this is the most tax efficient rule (e.g., see Dickson, Shoven, and Sialm $(2000)){ }^{19}$

Using these rules, I compute the value-weighted cost basis (VWCB):

$$
V W C B_{f, i}^{t}=\frac{\sum_{n=0}^{t} S_{f, i}^{t, t-n} \cdot P_{i}^{t, t-n}}{\sum_{n=0}^{t} S_{f, i}^{t, t-n}}
$$

where $S_{f, i}^{t, t-n}$ is the number of shares of stock $i$ purchased by fund $f$ at date $t-n$ that are still held at time $t$, and $P_{i}^{t, t-n}$ is the imputed price paid for these shares. I then calculate the dollar amount of the unrealized capital gain for fund-stock combination $f$, $i$ at time $t$ as:

$$
\text { CapitalGain }_{f, i}^{t}=P_{i}^{t}-V W C B_{f, i}^{t}
$$

To examine the effect of capital gains lock-in on earnings quality, the key explanatory variable that I use is $C P G L . C P G L$ is a firm-level measure computed as the dollar value of capital gains held by mutual funds divided by the company's

\footnotetext{
19 To impute prices, prior studies have used average, daily transaction weighted average, beginning of quarter, and end-of-quarter prices. To assign partial sales, prior studies have used highest-in-first-out, share-weighted average, last-in-first-out, and first-in-first out. The cross product of the four price rules and four sales rules results in 16 possible imputation methods. Prior studies have shown that all 16 methods result in very similar imputed capital gains and the choice of method does not materially affect results. See Jin (2006), Cici (2012) and Dimmock et al. (2018).
} 
beginning of quarter market capitalization. To test whether the effect of unrealized capital gains is indeed driven by tax motivation, I split $C P G L$ into aggregates for the high defined contribution mutual funds and for the low defined contribution mutual funds by creating separate aggregated variables for all mutual funds whose proportion of assets held by retirement funds is above and below the sample median, respectively. CPGL_TaxInSen is the dollar value of capital gains held by mutual funds with above median defined contribution plan ownership divided by market cap. CPGL_TaxSen is the dollar value of capital gains held by mutual funds with below median defined contribution plan ownership divided by market cap.

\subsection{Description of the control variables}

My objective is to measure the effect of capital gains lock-in on earnings quality. Capital gains by definition reflect stock price appreciation, which can be related to earnings quality for other reasons. For example, a well-performing firm whose stock price has risen in previous months has less incentive to manipulate earnings in order to achieve performance target. Thus, I control for recent stock returns by including previous 3-month, 6-month, and 12-month market adjusted buy-and-hold returns as independent variables. I also control for institutional ownership, firm size, firm age, market-to-book ratio, loss percentage, leverage, return on assets, and sales growth. ${ }^{20}$ Following the suggestion of Hribar and Nichols (2007), I control for sales volatility and operating cash flow volatility as well. Accounting data are obtained from Compustat, and stock data are from CRSP. Data on institutional ownership are obtained from the Thomson-Reuters 13F Database. All the continuous variables are winsorized at the $1^{\text {st }}$ and $99^{\text {th }}$ percentiles to mitigate the effects of possible outliers.

\footnotetext{
20 The selection of control variables largely follows prior research on earnings management, such as Liu (2016). In addition, my results are robust to control for mutual fund holdings.
} 
Detailed variable definitions are provided in Appendix A. Summary statistics are presented in Table 1. The mean CPGL_TaxSen and mean CPGL_TaxInSen are $0.38 \%$ and $-0.31 \%$, respectively. ${ }^{21}$ The mean $D A$ equals $4.51 \%$.

\section{Main analysis}

\subsection{Model specifications}

To estimate the effect of capital gains lock-in on earnings quality, I use the following models:

$$
\begin{aligned}
& E Q_{i t}=\beta C P G L_{i t}+\gamma^{\prime} X_{i t}+\delta_{i}+\delta_{t}+\varepsilon_{i t}, \\
& E Q_{i t}=\beta_{1} C P G L_{-} \text {TaxSen }_{i t}+\beta_{2} C P G L_{-} \text {TaxInSen }_{i t}+\gamma^{\prime} X_{i t}+\delta_{i}+\delta_{t}+\varepsilon_{i t},
\end{aligned}
$$

where $i$ indexes firms, and $t$ indexes time. $X_{i t}$ is the set of firm-level controls (including the constant). Return variables are measured as the beginning of the quarter and all other controls are measured as of the end of the quarter. $\delta_{i}$ and $\delta_{t}$ are firm and time (year-quarter) fixed effects, respectively. $\varepsilon_{i t}$ is the error term.

$E Q_{i t}$ denotes the earnings quality measures discussed in Section 3.2 and is measured as of the end of the quarter. CPGL $L_{i t}, C P G L_{-} T a x S e n_{i t}$, and CPGL_TaxInSen $i t$ are capital gains overhang measures which are measured as of the beginning of the quarter. I use the logistic regression when the dependent variable is restatement dummy, and ordinary least squares (OLS) elsewhere. Standard errors are double clustered by firm and by time.

Since capital gains lock-in does not affect tax-insensitive mutual funds, $\beta_{2}$ identifies the magnitude of relation between unrealized capital gains and earnings

\footnotetext{
${ }^{21}$ In Table 1, the mean of CPGL is not equal to the sum of mean CPGL_TaxSen and mean CPGL_TaxInSen. The reason is that, for some mutual funds, I do not have the information for the tax status of fund investors. Therefore, I construct another variable CPGL_NoTaxStatus to represent the dollar value of capital gains held by mutual funds for which I do not have DC plan ownership data divided by market cap. The sum of CPGL_TaxSen, CPGL_TaxInSen, and CPGL_NoTaxStatus is approximately equal to CPGL due to rounding.
} 
quality which is not attributed to lock-in. Hence, no prediction of the sign is made for variable CPGL_TaxInSen. The capital gains lock-in effect can be identified based on the difference between $\beta_{1}$ and $\beta_{2}$. Therefore, if the influence of the capital gains lock-in is indeed through the channel of capital gain tax, I expect that $\widehat{\beta_{1}}$ will be more negative than $\widehat{\beta_{2}}$ (expect for the accruals quality measure for which I expect $\widehat{\beta_{1}}$ to be more positive than $\widehat{\beta_{2}}$ ). I use a one-tailed test to evaluate whether the difference between the two coefficients is significant.

\subsubsection{Performance matched discretionary accruals}

In the main regression, the dependent variable $D A$ is calculated as the absolute value of performance matched discretionary accruals scaled by average total assets. The results are reported in Table 2 . In column 1, the key explanatory variable is $C P G L$. The coefficient on $C P G L$ is $-0.0313(p<0.001)$. Consistent with my hypothesis, the amount unrealized capital gains held by mutual funds is negatively associated with discretionary accruals, and thus is related to higher earnings quality. In terms of the economic effect, a one standard deviation (0.0873) increase in CPGL is associated with a decrease in earnings management of 0.0027 , which is around $6.04 \%$ of the mean $D A$ of 0.0451 . For the control variables, size is positively associated with earnings quality. Loss percentage, leverage, and sales growth are negatively related to earnings quality. More profitable firms tend to have high earnings quality. Firm with high cash flow volatility tends to have low earnings quality. All other control variables are not statistically significant.

Column 2 examines whether the effect of unrealized capital gains on earnings quality is due to tax reason. I test the effects of CPGL_TaxSen and CPGL_TaxInSen separately and expect the effect in column 1 to be concentrated among tax-sensitive mutual funds. Consistent with my prediction, the coefficient on CPGL_TaxSen is 
negative and is significant at the $1 \%$ level $(p<0.001)$. In contrast, the coefficient on CPGL_TaxInSen is negative but not significant $(p=0.158)$. In terms of economic significance, a one standard deviation (0.0253) increase in CPGL_TaxSen is associated with a decrease in earnings management of 0.0017 , which is around $3.80 \%$ of the mean DA of 0.0451. A one standard deviation (0.0261) increase in CPGL_TaxInSen is associated with a decrease in earnings management of $1.39 \%$ (evaluated at the sample mean). The coefficient on CPGL_TaxSen is approximately 2.82 times the coefficient on CPGL_TaxInSen and is 2.17 times the baseline coefficient on CPGL.

If capital gains lock-in improves earnings quality, then I should observe $\beta_{1}$ $\beta_{2}<0$. In column 2 , the difference between $\widehat{\beta_{1}}$ and $\widehat{\beta_{2}}$ is negative and statistically significant at the $5 \%$ level. Given that I am not able to perfectly seperate investors with different tax sensitivity, almost all the mutual funds under my analysis have at least some tax-exempt investors and at least some taxable investors. As a result, my estimates likely understate the true magnitude of the capital gains lock-in effect. The lock-in effect imposed by all the investors for a given firm is even stronger since the tax-sensitive mutual funds under my analysis represent only a fraction of all taxsensitive investors.

These results are consistent with my argument - mutual funds that are locked-in to a holding due to tax motivation are incentivized to monitor their portfolio companies more closely, resulting in higher earnings quality. Column 3 and column 4 differ from column 2, only in that I include 6-month and 3-month, instead of 12month, market adjusted buy-and-hold return as the control variable, respectively. All the inferences are qualitatively similar. ${ }^{22}$

\footnotetext{
${ }^{22}$ I also include 12-month, 6-month, and 3-month returns altogether in the regression and find similar results. Moreover, it is possible that the firm has good earning quality in the first place which causes the stock price increase and the capital gains. Although I have discussed in the introduction that such a reverse causality
} 


\subsubsection{Accruals quality using McNichols (2002) modification of Dechow and Dichev}

(2002)

I next employ an earnings attribute approach and report the results in Table 3. The dependent variable $D D$ is the absolute value of accruals quality measure based on modified Dechow and Dichev (2002) approach (McNichols, 2002) multiplied by negative one. All the results are consistent with my hypothesized capital gains lock-in effect. In column 1 , the coefficient on $C P G L$ is $0.0335(p<0.001)$, indicating that a one standard deviation (0.0869) increase in $C P G L$ is associated with an increase in accruals quality of 0.0029 , which is around $5.63 \%$ (in absolute value) of the mean $D D$ of -0.0517

In column 2, the coefficient on CPGL_TaxSen is significantly positive whereas CPGL_TaxInSen does not load significantly. A one standard deviation (0.0252) increase in CPGL_TaxSen is associated with an increase in accruals quality of 0.0021 , which is around $4.10 \%$ (in absolute value) of the mean $D D$ of -0.0517 . A one standard deviation (0.0260) increase in CPGL_TaxInSen is associated with an increase in accruals quality of $0.60 \%$ (evaluated at the sample mean). In terms of the economic significance, the coefficient on CPGL_TaxSen is almost 7.00 times the coefficient on CPGL_TaxInSen. The result of coefficient comparison test in the last row shows that the coefficient on CPGL_TaxSen is larger than the coefficient on CPGL_TaxInSen and that the difference is significant at the $1 \%$ level. The results support that tax-sensitive mutual funds have more incentive to monitor the firm and their monitoring improves

explanation seems unlikely to be a major concern of my study, I include past earnings quality as an additional control variable and the results are qualitatively unchanged. In addition, my results are largely similar after controlling for the quality of corporate governance (using either G-Index or E-Index), albeit statistically weaker. One likely reason is that requiring the availability of governance data substantially reduces the sample size. 
the firm's earnings quality as measured by the accruals quality. ${ }^{23}$

\subsubsection{Special items}

In Table 4, the dependent variable is the absolute value of special items scaled by total assets. In column $1, C P G L$ has a negative impact on earnings quality as measured by special items, which supports my hypothesis. A coefficient of -0.0304 ( $p$ $<0.001)$ on $C P G L$ indicates that a one standard deviation (0.0875) increase in unrealized capital gains is associated with a 0.0027 decrease in special items, which is around $35.91 \%$ of the mean $A B S S P I$ of 0.0074 .

In column 2, both CPGL_TaxSen and CPGL_TaxInSen are negatively related to the absolute value of special items. The coefficient difference test at the bottom of Table 4 shows that the size of the coefficient on CPGL_TaxSen is significantly larger at the 5\% level. For CPGL_TaxSen, a one standard deviation (0.0254) increase in unrealized capital gains among tax-sensitive mutual funds is associated with a 0.0016 decrease in special items, which is around $21.37 \%$ of the mean $A B S S P I$ of 0.0074 . For CPGL_TaxInSen, A one standard deviation (0.0261) increase in unrealized capital gains among tax-insensitive mutual funds is associated with a 0.0007 decrease in special items, which is around $9.99 \%$ of the mean $A B S S P I$ of 0.0074 . From the perspective of economic significance, the coefficient on CPGL_TaxSen is around 2.20 times the coefficient on CPGL_TaxInSen.

\subsubsection{Real earnings management}

Table 5 presents the results for real earnings management. In column 1, the dependent variable is $R M 1$ which combines the effects of overproduction and

\footnotetext{
23 In untabulated tests, following prior literature, I also use a dependent variable computed based on current total accruals. The results are qualitatively similar. CPGL_TaxSen loads significantly positive $(p<0.001)$ whereas the effect of CPGL_TaxInSen is not significant $(p=0.284)$. The difference is positive and significant at the $1 \%$ level.
} 
reduction of discretionary expenditures. The coefficient on $C P G L \_T a x S e n$ suggests a significant deterrence effect on real earnings management $(p=0.039)$ whereas the coefficient of CPGL_TaxInSen is not significant ( $p=0.807)$. The difference between the effects of CPGL_TaxSen and CPGL_TaxInSen is negative at the $10 \%$ significance level.

In column 2, the dependent variable is $R M 2 . R M 2$ combines abnormal cash flows from operation and abnormal discretionary expenditures. The estimate suggests that CPGL_TaxSen has a negative effect on RM2 $(p=0.061)$ while the effect of CPGL_TaxInSen is positive ( $p=0.045)$. The test result at the bottom of the table indicates that the difference between the two coefficients is negative at the $5 \%$ significance level.

In column 3 , the dependent variable is $R M$ which summarizes all three ways of real earnings management. The coefficient on CPGL_TaxSen is negative and significant $(p=0.016)$, but the coefficient on CPGL_TaxInSen is not significant ( $p=$ 0.158). Additional test suggests that the effect of $C P G L_{-}$TaxSen on $R M$ is more negative than CPGL_TaxInSen and that the difference is significant with a $p$-value of $0.013 .^{24}$

Overall, the results lend strong support to my hypothesis, and suggest that mutual funds who have unrealized capital gains, especially tax-sensitive mutual funds, are locked-in and have more incentive to monitor their portfolio firms. Their monitoring leads to a lower level of real earnings management activities. This finding is important because real activities manipulations have real consequences and

\footnotetext{
${ }^{24}$ In untabulated tests, I also construct three individual measures by taking absolute values of $A B C F O, A B P R O D$, and $A B D I S X$, and use them as the dependent variables to test my hypothesis. The results are statistically weak, but they are consistent with my expectation that the coefficient on CPGL_TaxSen is smaller (i.e., less positive or more negative) than the coefficient on CPGL_TaxInSen.
} 
therefore are costlier for shareholders.

\subsubsection{Restatements}

Table 6 presents the results for the restatement regressions. I run a series of panel logit regressions, since the dependent variables, $R E S$ and $R E S \_F R D$, are dummy variables. In column 1 and column 2, the dependent variable RES covers all types of accounting restatements. Since the coefficient on $C P G L$ is not significant, I separately examine the effect of unrealized capital gains for tax-sensitive mutual funds and taxinsensitive mutual funds. The coefficient on CPGL_TaxSen is -2.0457 , significant at the $5 \%$ level, suggesting that more unrealized capital gains attributable to tax-sensitive mutual funds lower the incidence of accounting restatements. The odds ratio estimate suggests that, when the unrealized capital gains of tax-sensitive mutual funds increase by a one standard deviation $(0.0251)$, the odds of restating the financial reports are reduced by $5.01 \%$, holding constant the values of other variables. ${ }^{25}$ Consistent with the lock-in effect, CPGL_TaxSen loads more negatively than CPGL_TaxInSen, and the difference between the two coefficient estimates is significant at the $1 \%$ level.

Column 3 and column 4 present the results for fraud-related accounting restatements. The coefficient on $C P G L$ is not significant. The coefficient on CPGL_TaxSen is negative and significant whereas the coefficient on CPGL_TaxInSen is not significant. My analysis of the odds ratio estimate indicates that, when the unrealized capital gains of tax-sensitive mutual funds increase by a one standard deviation (0.0251), the odds of restating the financial reports due to frauds are reduced by approximately $14.81 \%$, holding constant the values of other variables. ${ }^{26}$ The

\footnotetext{
25 This number is calculated as $e^{\text {coefficient on } C P G L_{-} T a x S e n \times 1 \text { sd change in CPGL_TaxSen }}-1=e^{-2.045731 \times 0.0251497}-1 \approx$ $-5.01 \%$.

${ }^{26}$ I also use linear probability model as an alternative model specification and find similar results.
} 
difference between the coefficient estimate of CPGL_TaxSen and that of CPGL_TaxInSen is negative and significant at the $1 \%$ level. The results are consistent with the monitoring role of tax-sensitive mutual funds since unrealized capital gains are especially effective in reducing the incidence of fraud-related restatements.

\section{Capital gains lock-in and earnings quality: Evidence from tax rate change}

The results presented thus far are consistent with my hypothesis that capital gains lock-in has a positive effect on earnings quality. However, tax-sensitive mutual funds and tax-insensitive mutual funds may differ on dimensions other than their tax sensitivity. For example, Sialm and Starks (2012) show that funds held extensively in tax-qualified defined contribution pension plans tend to have lower expense ratios and greater assets under management, and are part of larger fund families as compared to funds with lower defined contribution assets. One potential concern is that these or other fund characteristics may be correlated with tax sensitivity and responsible for the results. In order to address this concern, I conduct several additional tests. Specifically, I examine whether the documented relation between unrealized capital gains and earnings quality varies with the capital gains tax rate. For any given amount of unrealized taxable capital gains, the extent of lock-in should increase with the tax rate since the cost of realizing the gain increases. I, therefore, expect the positive relation between mutual funds' unrealized gains and earnings quality to be stronger when the capital gains tax rate is higher. In contrast, it is unlikely that the effects of other fund characteristics depend on the magnitude of capital gains tax rate. To implement my idea, I construct a variable, Taxrate, representing the long-term capital gains tax rate, which equals 28 in 1997Q1, 20 from 1997Q2 to 2003Q1, and 15 from 2003Q2 to the

end of the sample. I then interact Taxrate with CPGL_TaxSen and CPGL_TaxInSen to create two interaction variables $C P G L \_$TaxSen $\times$Taxrate and 
CPGL_TaxInSen $\times$ Taxrate. If my main results are driven by the capital gains lock-in for tax reason, I expect that Taxrate will moderate the effect of CPGL_TaxSen and that the moderating effect of Taxrate will not be observed for CPGL_TaxInSen.

I reexamine the findings in Table 2 and report the results in Table 7. In column 1, consistent with the capital gains lock-in effect, the coefficient on CPGL_TaxSen $\times$ Taxrate is negative and significant at the $5 \%$ level $(p=0.036)$ whereas the coefficient on CPGL_TaxInSen $\times$ Taxrate is not significant $(p=0.417) .{ }^{27}$

However, the results presented in the first column of Table 7 could also be consistent with time-series changes other than the changes in the capital gains tax rate (although it is not obvious why other time-series changes would have differential effects depending upon the tax status of the mutual funds' investors). To address this concern, I focus on the change in the long-term capital gains tax in 2003 (when it was lowered from $20 \%$ to $15 \%$ as a result of the Jobs and Growth Tax Relief Reconciliation Act (JGTRRA)) and examine a 3-year window and a 5-year window centered around the 2003 tax rate change. The shorter windows make it less likely that other time-series changes affect the results. ${ }^{28}$ I introduce two dummy variables. The first one is TR2, which equals one for the quarters from 1997Q2 to 2003Q1 and zero for other quarters. The second one is $T R 3$, which equals one for the quarters from 2003Q2 to the end of the sample and zero for other quarters. CPGL_TaxSen $\times$ TR2 and CPGL_TaxSen $\times T R 3$ are interaction terms between $C P G L \_T a x S e n$ and two tax regime

\footnotetext{
27 I use an alternative sample period from 1998 to 2008 and find qualitatively similar results.

28 The Taxpayer Relief Act of 1997 (TRA) reduces the U.S. long-term capital gains tax rate from $28 \%$ to $20 \%$, and then the JGTRRA of 2003 further cuts the rate to $15 \%$. I draw my inference based on the JGTRRA because I only have one quarter observations before the TRA and the results based on TRA may not be reliable. One caveat using the JFTRRA setting is that it changed both the capital gains tax rate and the dividend tax rate. The JRA setting is cleaner. However, I do not expect that capital gains tax sensitivity is systematically correlated with dividend tax sensitivity, and at the same time, that realized dividend income of mutual funds is systematically associated with the earnings quality of their portfolio firms. With that being said, I conduct additional analysis using 1997-1998 and 1997-1999 as two alternative window periods to address this concern and find qualitatively similar results.
} 
variables TR2 and TR3.CPGL_TaxInSen $\times T R 2$ and CPGL_TaxInSen $\times T R 3$ are constructed similarly. I expect the capital gains lock-in effect to be more pronounced before the tax cut. Therefore, the negative effect of CPGL_TaxSen on discretionary accruals compared with CPGL_TaxInSen is expected to be stronger during the earlier sample period (TR2) when the tax rate is higher.

If capital gains lock-in improves earnings quality due to tax reason. then I should observe $\beta\left(C P G L_{-}\right.$TaxSen $\times$TR2) $-\beta\left(C P G L_{-}\right.$TaxInSen $\times$TR2 $)<$ $\beta\left(C P G L_{-}\right.$TaxSen $\times$TR3 $)-\beta\left(C P G L_{-}\right.$TaxInSen $\times$TR3 $)$. Column 2 of Table 7 reports the results for sample period 2002-2004. Of all the variables of interest, only $C P G L \_T a x S e n \times T R 2$ is significant $(p=0.074)$, indicating that unrealized capital gains of tax-sensitive mutual funds lead to high earnings quality only when the capital gains tax rate is relatively high. Consistent with tax incentive, I find that the relation between earnings quality and the unrealized gains of tax-sensitive mutual funds decreases significantly from one year before to one year after the tax cut year $(p=$ 0.022). However, no similar change is observed for the unrealized gains of taxinsensitive mutual funds $(p=0.426)$. More importantly, the coefficient comparison test reported at the bottom of Table 7 is consistent with my prediction that the capital gains lock-in effect is stronger when the tax rate is higher $(p=0.031)$. In column 3 , I use an alternative sample period from 2001-2005. The results are almost the same as those presented in column 2. ${ }^{29}$ This set of results help to alleviate the concern that my results are driven by fund characteristics other than tax sensitivity and provide strong evidence for the tax explanation of my research findings.

\footnotetext{
${ }^{29}$ All the results are qualitatively similar with past earnings quality being included as an additional control variable.
} 


\section{Mechanism of capital gains lock-in effect: Evidence on the monitoring channel}

In this section, I aim to provide some evidence on whether locked-in mutual funds monitor the accounting practice of their portfolio firms by focusing on the concentration of mutual fund ownership. ${ }^{30}$ First, mutual funds with concentrated holdings have more incentive to monitor the firm. Shleifer and Vishny (1986) develop a theoretical model and establish that the presence of a large minority shareholder (i.e., concentrated ownership) provides a partial solution to the free-rider problem that occurs if each investor only holds a small stake. The authors argue that large shareholders monitor managers, which in turn increases firm value. In a firm with dispersed ownership structure, shareholders are discouraged from devoting resources to monitoring because everyone will freely benefit from this public good.

Concentrated shareholders with a large stake in a company can overcome this free rider problem. They play an active role in monitoring because they can internalize the monitoring benefits in proportion to their ownership and because the monitoring benefits accrued to them are higher than the monitoring costs. Therefore, mutual funds with concentrated holdings have a greater incentive to monitor because they appropriate a larger part of the appreciation of the shares due to improved earnings quality. Empirically, Chen, Harford, and Li (2007) find that concentrated holdings by independent long-term institutions are associated with better mergers and the withdrawal of bad mergers. Burns et al. (2010) show that concentrated ownership induces greater monitoring and mitigates the incentives for firms to misreport.

Second, mutual funds with concentrated holdings have more power to

\footnotetext{
${ }^{30}$ My earlier finding that capital gains lock-in is especially effective in reducing fraud-related restatements lends some preliminary support to the monitoring channel, given that mutual funds base their monitoring strategy on cost and benefit analysis and that preventing fraud-related restatements from happening brings more benefit for shareholders.
} 
influence the managers. From the perspective of portfolio firm managers, they would give priority to the request by blockholders since concentrated ownership enables large shareholders to have more ability to influence the management. Given the above, the monitoring channel suggests that the capital gains lock-in effect will be more pronounced when the mutual fund holdings are more concentrated. ${ }^{31}$

To test my prediction, I use the Herfindahl-Hirschman Index, $H H I$, as a measure of the concentration of mutual fund ownership at the portfolio firm level, with a smaller value indicating lower concentration. $H H I$ is calculated as follows. For each mutual fund holding, I take its value as a percentage of total mutual fund holdings in that company for that quarter, square this percentage, and sum up the squared percentages across all funds for that firm-quarter. HHI_of_TaxSen and HHI_of_TaxInSen are calculated as above, but include only holdings by tax-sensitive mutual funds and tax-insensitive mutual funds, respectively. I then create three interaction variables, $C P G L \times H H I, C P G L \_T a x S e n \times H H I \_o f$ TaxSen and CPGL_TaxInSen $\times H H I \_o f$ TaxInSen. First, I expect that the effect of CPGL $\times H H I$ to be negative. Second, if tax-sensitive mutual funds monitor firms to a greater extent, then I expect the effect of interaction term CPGL_TaxSen $\times H H I \_f \_T a x S e n$ to be negative and that this pattern will be less strong for CPGL_TaxInSen $\times H H I \_o f \_T a x I n S e n$.

Table 8 presents the results. Column 1 provides the baseline results where $C P G L$ and $C P G L \times H H I$ are explanatory variables of interest. The coefficient on $C P G L$ is negative but not significant, suggesting that unrealized capital gains do not have a significant effect on earnings quality when $H H I$ equals zero (i.e., the least concentrated

\footnotetext{
31 Mutual funds cannot select the extent of capital gains lock-in based on the concentration level of mutual fund holdings for a given portfolio firm because unrealized capital gains and the tax status of fund investors are not identifiable a priori.
} 
case). $C P G L \times H H I$ loads negatively, consistent with my prediction, and the coefficient is significant at the $1 \%$ level. When $H H I$ equals to one (i.e., the most concentrated case), $C P G L$ has a significantly positive effect on earnings quality $(\mathrm{p}<0.001)$.

In column 2, I separate the capital gains overhang measure into tax-sensitive group and tax-insensitive group in order to test whether the result in column 1 is driven by the tax-sensitive mutual funds. I find that both CPGL_TaxSen $\times H H I \_o f$ TaxSen and CPGL_TaxInSen $\times H H I \_o f \_T a x I n S e n$ loads negatively and the effects are significant. Consistent with the monitoring effort of taxsensitive mutual funds, the coefficient on CPGL_TaxSen $\times H H I \_f \_T a x S e n$ is around 1.43 times the coefficient on CPGL_TaxInSen $\times H H I$ of_TaxInSen, although the difference is not statistically significant ( $p=0.317$ ). I also find that, in the most concentrated case where both HHI_of_TaxSen and HHI_of_TaxInSen equal ones, the effect of unrealized capital gains is more pronounced for tax-sensitive mutual funds than for tax-insensitive mutual funds $(p=0.015)$ but this pattern cannot be observed in the least concentrated case $(p=0.207)$.

In addition, I use the coefficient comparison test to further examine my prediction. For tax-sensitive mutual funds, I construct two dummy variables. The first variable is TaxSen_HighConc which equals one if HHI_of_TaxSen is above the median, and zero otherwise. The second variable is TaxSen_LowConc which equals one if HHI_of_TaxSen is below the median, and zero otherwise. Two similar variables, TaxInSen_HighConc and TaxInSen_LowConc are created for tax-insensitive mutual funds to indicate whether the HHI_of_TaxInSen is above or below the median, respectively. I then interact these four concentration indicator variables with respective unrealized capital gains variables. If capital gains lock-in incentivizes tax-sensitive mutual funds to monitor the firm and improve its earnings quality, I should observe 
$\beta\left(C P G L_{-}\right.$TaxSen $\times$TaxSen_HighConc $)-\beta\left(C P G L_{-}\right.$TaxInSen $\times$

TaxInSen_HighConc $)<\beta\left(C P G L_{-}\right.$TaxSen $\times$TaxSen_LowConc $)-$

$\beta\left(C P G L \_T a x I n S e n \times\right.$ TaxInSen_LowConc $)$. Column 3 of Table 8 reports the results.

Consistent with my prediction, the effect of unrealized capital gains is most

statistically and economically significant for tax-sensitive mutual funds and when

mutual fund holdings are highly concentrated $(\hat{\beta}=-0.1007)$. The capital gains lock-in

effect is significant when the ownership concentration is high $(p=0.003)$, but is not

when the concentration is low ( $p=0.314)$. Most importantly, the coefficient

comparison test in the last row of Table 8 shows that the lock-in effect is more

pronounced when the concentration is higher $(p=0.014) .{ }^{32}$

Together, the findings in this section are consistent with my prediction. In

particular, the evidence suggests that locked-in mutual funds are more likely to engage in monitoring activities to improve earnings quality when mutual fund holdings are more concentrated.

\section{Conclusion}

Empirical research in accounting and finance generally documents that institutional investors have strong power to shape firm's accounting policy. I examine a factor that could affect mutual funds' monitoring incentive and in turn could influence firms' earnings quality. In particular, my research question is whether and how capital gains lock-in may affect a firm's earnings quality. Consistent with my hypothesis, I find that unrealized capital gains are positively related to earnings

\footnotetext{
32 In terms of the economic magnitude, for the tax-sensitive-high-concentration group, a one standard deviation (0.0281) increase in unrealized capital gains among tax-sensitive mutual funds is associated with a 0.0028 decrease in $D A$ for firms with highly concentrated mutual fund ownership (calculated as $0.0281 \times 0.1008$ ), which is around $5.81 \%$ of the mean $D A$ of 0.0487 . Similarly, I calculate the marginal effects for the tax-sensitive-low-concentration, tax-insensitive-high-concentration, and tax-insensitive-low-concentration groups, which are $0.37 \%, 2.07 \%$, and $1.64 \%$, respectively.
} 
quality. As a consequence of lock-in, tax-sensitive mutual funds have statistically and economically more positive impact on earnings quality than tax-insensitive mutual funds.

To address the concern that my results are driven by fund characteristics other than tax sensitivity, I first predict and find that capital gains lock-in has a stronger effect on earnings quality when capital gains tax rate is higher. Second, using the tax cut induced by the Jobs and Growth Tax Relief Reconciliation Act of 2003, I find that the effect of unrealized capital gains is more pronounced for tax-sensitive mutual funds before the cut of capital gains tax. In addition, the positive relation between earnings quality and the unrealized gains of tax-sensitive mutual funds decreases significantly from one year (or two years) before to one year (or two years) after the tax cut year. However, no similar change is observed for tax-insensitive mutual funds. More importantly, the decrease in the effect of unrealized capital gains as a result of tax cut is more pronounced for tax-sensitive mutual funds than for tax-insensitive mutual funds. Altogether, my findings provide strong evidence for the tax explanation of capital gains lock-in effect.

To examine whether locked-in funds improve earnings quality via monitoring, I test whether the capital gains lock-in effect is moderated by the concentration of mutual fund holdings. Consistent with the monitoring channel, I find that capital gains lock-in has a more pronounced effect on earnings quality when the ownership concentration is higher.

To my best knowledge, I am the first to examine the capital gains lock-in effect on a firm's accounting policy. I believe that understanding how capital gains lock-in affects corporate behavior is important given the increasingly prominent role of mutual funds in the financial market. 


\section{References}

Aboody, D., Hughes, J., \& Liu, J. (2005). Earnings quality, insider trading, and cost of capital. Journal of Accounting Research, 43(5), 651-673.

Admati, A. R., \& Pfleiderer, P. (2009). The "Wall Street Walk" and shareholder activism: Exit as a form of voice. Review of Financial Studies, 22(7), 26452685.

Amihud, Y. (2002). Illiquidity and stock returns: cross-section and time-series effects. Journal of Financial Markets, 5(1), 31-56.

Anderson, R. C., Mansi, S. A., \& Reeb, D. M. (2004). Board characteristics, accounting report integrity, and the cost of debt. Journal of Accounting and Economics, 37(3), 315-342.

Ayers, B. C., Lefanowicz, C. E., \& Robinson, J. R. (2003). Shareholder taxes in acquisition premiums: The effect of capital gains taxation. Journal of Finance, $58(6), 2783-2801$.

Ayers, B. C., Li, O. Z., \& Robinson, J. R. (2008). Tax-induced trading around the Taxpayer Relief Act of 1997. Journal of the American Taxation Association, 30(1), 77-100.

Baig, A., DeLisle, J., \& Zaynutdinova, G. R. (2018). Passive ownership and earnings manipulation. Working paper.

Balakrishnan, K., Blouin, J., \& Guay, W. (2018). Tax Aggressiveness and Corporate Transparency. The Accounting Review, In-Press.

Ball, R. (2001). Infrastructure requirements for an economically efficient system of public financial reporting and disclosure. Brookings-Wharton Papers on Financial Services, 2001(1), 127-169.

Bange, M. M., \& De Bondt, W. F. (1998). R\&D budgets and corporate earnings targets. Journal of Corporate Finance, 4(2), 153-184.

Barth, M. E., Konchitchki, Y., \& Landsman, W. R. (2013). Cost of capital and earnings transparency. Journal of Accounting and Economics, 55(2-3), 206-224.

Beatty, A., Ramesh, K., \& Weber, J. (2002). The importance of accounting changes in debt contracts: the cost of flexibility in covenant calculations. Journal of Accounting and Economics, 33(2), 205-227.

Bergstresser, D., \& Poterba, J. (2002). Do after-tax returns affect mutual fund inflows? Journal of Financial Economics, 63(3), 381-414.

Bhattacharya, N., Ecker, F., Olsson, P. M., \& Schipper, K. (2012). Direct and mediated associations among earnings quality, information asymmetry, and the cost of equity. The Accounting Review, 87(2), 449-482.

Blaylock, B., Gaertner, F., \& Shevlin, T. (2015). The association between book-tax conformity and earnings management. Review of Accounting Studies, 20(1), 141-172.

Blouin, J. L., Bushee, B. J., \& Sikes, S. A. (2017). Measuring tax-sensitive institutional investor ownership. The Accounting Review, 92(6), 49-76.

Blouin, J. L., Raedy, J. S., \& Shackelford, D. A. (2003). Capital gains taxes and equity trading: Empirical evidence. Journal of Accounting Research, 41(4), 611-651. 
Bratten, B., Payne, J. L., \& Thomas, W. B. (2016). Earnings management: Do firms play "follow the leader"? Contemporary Accounting Research, 33(2), 616-643.

Brown, L. D., Call, A. C., Clement, M. B., \& Sharp, N. Y. (2018). Managing the narrative: Investor relation officers and corporate disclosure. Journal of Accounting and Economics, In Press.

Burns, N., Kedia, S., \& Lipson, M. (2010). Institutional ownership and monitoring: Evidence from financial misreporting. Journal of Corporate Finance, 16(4), 443-455.

Bushee, B. J. (1998). The influence of institutional investors on myopic R\&D investment behavior. The Accounting Review, 73(3), 305-333.

Bushee, B. J. (2001). Do institutional investors prefer near-term earnings over longrun value? Contemporary Accounting Research, 18(2), 207-246.

Chen, X., Harford, J., \& Li, K. (2007). Monitoring: Which institutions matter? Journal of Financial Economics, 86(2), 279-305.

Chung, R., Firth, M., \& Kim, J.-B. (2002). Institutional monitoring and opportunistic earnings management. Journal of Corporate Finance, 8(1), 29-48.

Cici, G. (2012). The prevalence of the disposition effect in mutual funds' trades. Journal of Financial and Quantitative Analysis, 47(4), 795-820.

Coffee, J. C. (1991). Liquidity versus control: The institutional investor as corporate monitor. Columbia Law Review, 91(6), 1277-1368.

Cohen, D. A., Dey, A., \& Lys, T. Z. (2008). Real and accrual-based earnings management in the pre-and post-Sarbanes-Oxley periods. The Accounting Review, 83(3), 757-787.

Dai, Z., Maydew, E., Shackelford, D. A., \& Zhang, H. H. (2008). Capital gains taxes and asset prices: Capitalization or lock - in? Journal of Finance, 63(2), 709742.

Dechow, P. M., \& Dichev, I. D. (2002). The quality of accruals and earnings: The role of accrual estimation errors. The Accounting Review, 77(s-1), 35-59.

Dechow, P. M., Ge, W., \& Schrand, C. (2010). Understanding earnings quality: A review of the proxies, their determinants and their consequences. Journal of Accounting and Economics, 50(2-3), 344-401.

Dechow, P. M., Sloan, R., \& Sweeney, A. (1996). Causes and consequences of earnings manipulation. Contemporary Accounting Research, 13(1), 1-36.

Dickson, J., Shoven, J. B., \& Sialm, C. (2000). Tax externalities of equity mutual funds. National Tax Journal, 53(3), 607-628.

Dimmock, S. G., Gerken, W. C., Ivković, Z., \& Weisbenner, S. J. (2018). Capital gains lock-in and governance choices. Journal of Financial Economics, 127(1), 113135.

Donohoe, M. P., \& Robert Knechel, W. (2014). Does corporate tax aggressiveness influence audit pricing? Contemporary Accounting Research, 31(1), 284-308.

Edmans, A. (2014). Blockholders and corporate governance. Annual Review of Financial Economics, 6(1), 23-50. 
Erickson, M., Hanlon, M., \& Maydew, E. L. (2004). How much will firms pay for earnings that do not exist? Evidence of taxes paid on allegedly fraudulent earnings. The Accounting Review, 79(2), 387-408.

Feldstein, M., Slemrod, J., \& Yitzhaki, S. (1980). The effects of taxation on the selling of corporate stock and the realization of capital gains. Quarterly Journal of Economics, 94(4), 777-791.

Fos, V., \& Kahn, C. M. (2014). Governance through threat of voice and threat of exit: Complements or substitutes? Working paper.

Francis, J., LaFond, R., Olsson, P., \& Schipper, K. (2005). The market pricing of accruals quality. Journal of Accounting and Economics, 39(2), 295-327.

Francis, J., LaFond, R., Olsson, P. M., \& Schipper, K. (2004). Costs of equity and earnings attributes. The Accounting Review, 79(4), 967-1010.

Frank, M. M., Lynch, L. J., \& Rego, S. O. (2009). Tax reporting aggressiveness and its relation to aggressive financial reporting. The Accounting Review, 84(2), 467496.

Frazzini, A. (2006). The disposition effect and underreaction to news. Journal of Finance, 61(4), 2017-2046.

Freeman, R., \& Tse, S. (1992). An earnings prediction approach to examining intercompany information transfers. Journal of Accounting and Economics, 15(4), 509-523.

French, K. R. (2008). Presidential address: The cost of active investing. Journal of Finance, 63(4), 1537-1573.

Ge, W., \& Kim, J.-B. (2014). Real earnings management and the cost of new corporate bonds. Journal of Business Research, 67(4), 641-647.

Graham, J. R., Harvey, C. R., \& Rajgopal, S. (2005). The economic implications of corporate financial reporting. Journal of Accounting and Economics, 40(1-3), $3-73$.

Graham, J. R., Li, S., \& Qiu, J. (2008). Corporate misreporting and bank loan contracting. Journal of Financial Economics, 89(1), 44-61.

Guenther, D. A. (1994). Earnings management in response to corporate tax rate changes: Evidence from the 1986 Tax Reform Act. The Accounting Review, 230-243.

Guthrie, K., \& Sokolowsky, J. (2010). Large shareholders and the pressure to manage earnings. Journal of Corporate Finance, 16(3), 302-319.

Hanlon, M., Krishnan, G. V., \& Mills, L. F. (2012). Audit fees and book-tax differences. Journal of the American Taxation Association, 34(1), 55-86.

Harford, J., Kecskes, A., \& Mansi, S. (2017). Do long-term investors improve corporate decision making? Journal of Corporate Finance.

Healy, P. M. (1985). The effect of bonus schemes on accounting decisions. Journal of Accounting and Economics, 7(1-3), 85-107.

Hribar, P., \& Jenkins, N. T. (2004). The effect of accounting restatements on earnings revisions and the estimated cost of capital. Review of Accounting Studies, 9(23), 337-356. 
Hribar, P., \& Nichols, D. C. (2007). The use of unsigned earnings quality measures in tests of earnings management. Journal of Accounting Research, 45(5), 10171053.

Huddart, S., \& Narayanan, V. (2002). An empirical examination of tax factors and mutual funds' stock sales decisions. Review of Accounting Studies, 7(2-3), 319341.

Ivković, Z., Poterba, J., \& Weisbenner, S. (2005). Tax-motivated trading by individual investors. American Economic Review, 95(5), 1605-1630.

Ivković, Z., \& Weisbenner, S. (2009). Individual investor mutual fund flows. Journal of Financial Economics, 92(2), 223-237.

Jin, L. (2006). Capital gains tax overhang and price pressure. Journal of Finance, 61(3), 1399-1431.

Kacperczyk, M., Sialm, C., \& Zheng, L. (2006). Unobserved actions of mutual funds. Review of Financial Studies, 21(6), 2379-2416.

Kahn, C., \& Winton, A. (1998). Ownership structure, speculation, and shareholder intervention. Journal of Finance, 53(1), 99-129.

Kahneman, D., \& Tversky, A. (1979). Prospect theory: An analysis of decision under risk. Econometrica, 47(2), 263-292.

Karpoff, J. M., Koester, A., Lee, D. S., \& Martin, G. S. (2017). Proxies and databases in financial misconduct research. The Accounting Review, 92(6), 129-163.

Kim, D., \& Qi, Y. (2010). Accruals quality, stock returns, and macroeconomic conditions. The Accounting Review, 85(3), 937-978.

Kim, J.-B., Li, Y., \& Zhang, L. (2011). Corporate tax avoidance and stock price crash risk: Firm-level analysis. Journal of Financial Economics, 100(3), 639-662.

Kim, J.-B., \& Sohn, B. C. (2013). Real earnings management and cost of capital. Journal of Accounting and Public Policy, 32(6), 518-543.

Kirschenheiter, M., \& Melumad, N. D. (2002). Can "big bath" and earnings smoothing co-exist as equilibrium financial reporting strategies? Journal of Accounting Research, 40(3), 761-796.

Klein, P. (2001). The capital gain lock-in effect and long-horizon return reversal. Journal of Financial Economics, 59(1), 33-62.

Koh, P.-S. (2007). Institutional investor type, earnings management and benchmark beaters. Journal of Accounting and Public Policy, 26(3), 267-299.

Kothari, S. P., Leone, A. J., \& Wasley, C. E. (2005). Performance matched discretionary accrual measures. Journal of Accounting and Economics, 39(1), 163-197.

Kravet, T., \& Shevlin, T. (2010). Accounting restatements and information risk. Review of Accounting Studies, 15(2), 264-294.

Lafond, R., \& Roychowdhury, S. (2008). Managerial ownership and accounting conservatism. Journal of Accounting Research, 46(1), 101-135. 
Landsman, W. R., \& Shackelford, D. A. (1995). The lock-in effect of capital gains taxes: Evidence from the RJR Nabisco leveraged buyout. National Tax Journal, 48(2), 245-259.

Lara, J. M. G., Osma, B. G., \& Penalva, F. (2011). Conditional conservatism and cost of capital. Review of Accounting Studies, 16(2), 247-271.

Lennox, C., Lisowsky, P., \& Pittman, J. (2013). Tax aggressiveness and accounting fraud. Journal of Accounting Research, 51(4), 739-778.

Levit, D. (2018). Soft shareholder activism. Working paper.

Li, O. Z., Lin, Y., \& Robinson, J. R. (2016). The effect of capital gains taxes on the initial pricing and underpricing of IPOs. Journal of Accounting and Economics, 61(2-3), 465-485.

Liu, X. (2016). Corruption culture and corporate misconduct. Journal of Financial Economics, 122(2), 307-327.

Maug, E. (1998). Large shareholders as monitors: Is there a trade-off between liquidity and control? Journal of Finance, 53(1), 65-98.

McCahery, J. A., Sautner, Z., \& Starks, L. T. (2016). Behind the scenes: The corporate governance preferences of institutional investors. Journal of Finance, 71(6), 2905-2932.

McNichols, M. F. (2002). Discussion of the quality of accruals and earnings: The role of accrual estimation errors. The Accounting Review, 77(s-1), 293-315.

Murphy, K. J., \& Zimmerman, J. L. (1993). Financial performance surrounding CEO turnover. Journal of Accounting and Economics, 16(1-3), 273-315.

Odean, T. (1998). Are investors reluctant to realize their losses? Journal of Finance, 53(5), 1775-1798.

Palmrose, Z.-V., Richardson, V. J., \& Scholz, S. (2004). Determinants of market reactions to restatement announcements. Journal of Accounting and Economics, 37(1), 59-89.

Ramalingegowda, S., \& Yu, Y. (2012). Institutional ownership and conservatism. Journal of Accounting and Economics, 53(1-2), 98-114.

Reese, W. A. (1998). Capital gains taxation and stock market activity: Evidence from IPOs. Journal of Finance, 53(5), 1799-1819.

Roychowdhury, S. (2006). Earnings management through real activities manipulation. Journal of Accounting and Economics, 42(3), 335-370.

Scholes, M. S., Wilson, G. P., \& Wolfson, M. A. (1992). Firms' responses to anticipated reductions in tax rates: The tax reform act of 1986. Journal of Accounting Research, 30(Supplement), 161-185.

Shefrin, H., \& Statman, M. (1985). The disposition to sell winners too early and ride losers too long: Theory and evidence. Journal of Finance, 40(3), 777-790.

Shleifer, A., \& Vishny, R. W. (1986). Large shareholders and corporate control. Journal of Political Economy, 94(3, Part 1), 461-488.

Sialm, C., \& Starks, L. (2012). Mutual fund tax clienteles. Journal of Finance, 67(4), 1397-1422. 
Sialm, C., Starks, L. T., \& Zhang, H. (2015). Defined contribution pension plans: Sticky or discerning money? Journal of Finance, 70(2), 805-838.

Sialm, C., \& Zhang, H. (2018). Tax-efficient asset management: Evidence from equity mutual funds. Working paper.

Sikes, S. A. (2017). Capital gains lock-in and share repurchases. Working paper.

Thomas, J., \& Zhang, F. (2008). Overreaction to intra-industry information transfers? Journal of Accounting Research, 46(4), 909-940.

Velury, U., \& Jenkins, D. S. (2006). Institutional ownership and the quality of earnings. Journal of Business Research, 59(9), 1043-1051.

Watts, R. L., \& Zimmerman, J. L. (1978). Towards a positive theory of the determination of accounting standards. The Accounting Review, 53(1), 112-134.

Wittenberg-Moerman, R. (2008). The role of information asymmetry and financial reporting quality in debt trading: Evidence from the secondary loan market. Journal of Accounting and Economics, 46(2-3), 240-260.

Yermack, D. (2010). Shareholder voting and corporate governance. Annual Review of Financial Economics, 2(1), 103-125. 


\begin{tabular}{|c|c|}
\hline Variable & Definition \\
\hline$D A$ & $\begin{array}{l}\text { Absolute value of discretionary accruals computed according } \\
\text { to Kothari et al. (2005). }\end{array}$ \\
\hline$D D$ & $\begin{array}{l}\text { Accruals quality measure computed according to the } \\
\text { modified Dechow and Dichev (2002) model (McNichols, } \\
\text { 2002). }\end{array}$ \\
\hline$A B S S P I$ & $\begin{array}{l}\text { Absolute value of special items (Compustat variable: } S P I Q \text { ) } \\
\text { scaled by total assets (Compustat variable: } A T Q \text { ). }\end{array}$ \\
\hline$A B C F O$ & $\begin{array}{l}\text { The level of abnormal cash flows from operations multiplied } \\
\text { by negative one. Variable is calculated according to } \\
\text { Roychowdhury (2006) and Cohen et al. (2008). }\end{array}$ \\
\hline$A B P R O D$ & $\begin{array}{l}\text { The level of abnormal production costs, where production } \\
\text { costs are the sum of cost of goods sold (Compustat variable: } \\
C O G S Q \text { ) and the change in inventories (Compustat variable: } \\
\text { INVTQ). Variable is calculated according to Roychowdhury } \\
\text { (2006) and Cohen et al. (2008). }\end{array}$ \\
\hline$A B D I S X$ & $\begin{array}{l}\text { The level of abnormal discretionary expenses multiplied by } \\
\text { negative one, where discretionary expenses are the sum of } \\
\text { R\&D expenses (Compustat variable: } X R D Q \text { ) and SG\&A } \\
\text { expenses (Compustat variable: } X S G A Q) \text {. Variable is } \\
\text { calculated according to Roychowdhury (2006) and Cohen et } \\
\text { al. (2008). }\end{array}$ \\
\hline$R M 1$ & $\begin{array}{l}\text { The absolute value of the sum of standardized } A B D I S X \text { and } \\
\text { standardized } A B P R O D .\end{array}$ \\
\hline$R M 2$ & $\begin{array}{l}\text { The absolute value of the sum of standardized } A B C F O \text { and } \\
\text { standardized } A B D I S X \text {. }\end{array}$ \\
\hline$R M$ & $\begin{array}{l}\text { The absolute value of the sum of standardized } A B C F O \text {, } \\
\text { standardized } A B P R O D \text {, and standardized } A B D I S X \text {. }\end{array}$ \\
\hline$R E S$ & $\begin{array}{l}\text { A dummy variable that equals one if the fiscal year-quarter } \\
\text { end falls between } R E S \_B E G I N_{-} D A T E \text { and } R E S \_E N D \_D A T E \text {, } \\
\text { and zero otherwise. }\end{array}$ \\
\hline RES_FRD & $\begin{array}{l}\text { A dummy variable that equals one if the firm has restated } \\
\text { current quarter financial statements due to fraud-related } \\
\text { reasons, and zero otherwise. RES_FRD is defined using two } \\
\text { variables taken from the Audit Analytics: RES_FRAUD } \\
\text { indicates fraud and } R E S \_S E C \_I N V E S T \text { indicates that a filing } \\
\text { associated with a restatement disclosed an SEC investigation } \\
\text { of the firm. }\end{array}$ \\
\hline$C P G L$ & $\begin{array}{l}\text { A firm-level measure computed as the dollar value of capital } \\
\text { gains held by mutual funds divided by the company's } \\
\text { beginning of quarter market capitalization. }\end{array}$ \\
\hline CPGL TaxSen & A firm-level measure computed as the dollar value of capital \\
\hline
\end{tabular}




\begin{tabular}{|c|c|}
\hline & $\begin{array}{l}\text { gains held by mutual funds with below median defined } \\
\text { contribution plan ownership divided by the company's } \\
\text { beginning of quarter market capitalization. }\end{array}$ \\
\hline CPGL_TaxInSen & $\begin{array}{l}\text { A firm-level measure computed as the dollar value of capital } \\
\text { gains held by mutual funds with above median defined } \\
\text { contribution plan ownership divided by the company's } \\
\text { beginning of quarter market capitalization. }\end{array}$ \\
\hline Inst_ownership & $\begin{array}{l}\text { Institutional ownership level divided by total shares } \\
\text { outstanding. }\end{array}$ \\
\hline Size & $\begin{array}{l}\text { The natural logarithm of total assets (Compustat variable: } \\
A T Q)\end{array}$ \\
\hline Age & $\begin{array}{l}\text { The natural logarithm of one plus the number of years the } \\
\text { firm has been in Compustat. }\end{array}$ \\
\hline$M B$ & $\begin{array}{l}\text { Market value of assets (Compustat variables: } C S H O Q \times \\
P R C C Q+P S T K Q+D L T T Q+D L C Q) \text { divided by book } \\
\text { value of assets (Compustat variable: } A T Q) \text {. }\end{array}$ \\
\hline Loss & $\begin{array}{l}\text { A dummy variable equal to one if the firm has consistent } \\
\text { negative net incomes before extraordinary items (Compustat } \\
\text { variable: } I B Q \text { ) during the last four quarters, and zero } \\
\text { otherwise. }\end{array}$ \\
\hline Leverage & $\begin{array}{l}\text { Debt (Compustat variables: } D L T T Q+D L C Q \text { ) divided by } \\
\text { book value of assets (Compustat variable: } A T Q \text { ). }\end{array}$ \\
\hline$R O A$ & $\begin{array}{l}\text { Operating income before depreciation (Compustat variable: } \\
O I B D P Q \text { ) divided by total assets (Compustat variable: } A T Q \text { ). }\end{array}$ \\
\hline Sales_volatility & $\begin{array}{l}\text { The standard deviation of scaled sales. Sales (Compustat } \\
\text { variable: } S A L E Q \text { ) are scaled by average total assets (the } \\
\text { average of } A T Q \text { and one-quarter lagged } A T Q \text { ). Standard } \\
\text { deviation is measured over quarters } q-19 \text { to } q \text { where } q \text { is the } \\
\text { current quarter. }\end{array}$ \\
\hline CFO_volatility & $\begin{array}{l}\text { The standard deviation of scaled operating cash flows. Cash } \\
\text { flows from operating activities are scaled by average total } \\
\text { assets (the average of } A T Q \text { and one-quarter lagged } A T Q \text { ). } \\
\text { Standard deviation is measured over quarters } q-19 \text { to } q \text { where } \\
q \text { is the current quarter. }\end{array}$ \\
\hline Sales_growth & $\begin{array}{l}\text { Sales (Compustat variable: } S A L E Q \text { ) in the current quarter } \\
\text { minus the sales in the same quarter of the previous fiscal } \\
\text { year, divided by sales in the same quarter of the previous } \\
\text { fiscal year. }\end{array}$ \\
\hline Return_12m & $\begin{array}{l}\text { 12-month market adjusted buy-and-hold return which ends at } \\
\text { the beginning of the current quarter. }\end{array}$ \\
\hline Return_6m & $\begin{array}{l}\text { 6-month market adjusted buy-and-hold return which ends at } \\
\text { the beginning of the current quarter. }\end{array}$ \\
\hline Return_3m & 3-month market adjusted buy-and-hold return which ends at \\
\hline
\end{tabular}




\begin{tabular}{|c|c|}
\hline & the beginning of the current quarter. \\
\hline Taxrate & $\begin{array}{l}\text { Long-term capital gains tax rate, which equals } 28 \text { in } 1997 \mathrm{Q} 1 \text {, } \\
20 \text { from } 1997 \mathrm{Q} 2 \text { to } 2003 \mathrm{Q} 1 \text {, and } 15 \text { from } 2003 \mathrm{Q} 2 \text { to the end } \\
\text { of the sample. }\end{array}$ \\
\hline$T R 2$ & $\begin{array}{l}\text { A dummy variable that equals one for the quarters from } \\
\text { 1997Q2 to 2003Q1, and zero for other quarters. }\end{array}$ \\
\hline$T R 3$ & $\begin{array}{l}\text { A dummy variable that equals one for the quarters from } \\
2003 \text { Q2 to the end of the sample, and zero for other quarters. }\end{array}$ \\
\hline$H H I$ & $\begin{array}{l}\text { For each mutual fund holding, I take its value as a percentage } \\
\text { of the firm's market capitalization, square this percentage, } \\
\text { and sum up the squared percentages across all funds for that } \\
\text { firm-quarter to get } H H I \text {. }\end{array}$ \\
\hline HHI_of_TaxSen & $\begin{array}{l}\text { HHI_of_TaxSen is calculated similarly as } H H I \text {, but include } \\
\text { only holdings by tax-sensitive mutual funds. }\end{array}$ \\
\hline HHI_of_TaxInSen & $\begin{array}{l}\text { HHI_of_TaxInSen is calculated similarly as } H H I \text {, but include } \\
\text { only holdings by tax-insensitive mutual funds. }\end{array}$ \\
\hline TaxSen_HighConc & $\begin{array}{l}\text { A dummy variable that equals one if } H H I \_o f \_T a x S e n \text { is above } \\
\text { the mean, and zero otherwise. }\end{array}$ \\
\hline TaxSen_LowConc & $\begin{array}{l}\text { A dummy variable that equals one if HHI_of_TaxSen is } \\
\text { below the mean, and zero otherwise. }\end{array}$ \\
\hline TaxInSen_HighConc & $\begin{array}{l}\text { A dummy variable that equals one if } H H I \_o f \_T a x I n S e n \text { is } \\
\text { above the mean, and zero otherwise. }\end{array}$ \\
\hline TaxInSen_LowConc & $\begin{array}{l}\text { A dummy variable that equals one if } H H I \_o f \_T a x I n S e n \text { is } \\
\text { below the mean, and zero otherwise. }\end{array}$ \\
\hline
\end{tabular}


Table 1. Description of variables

This table presents summary statistics for the samples used in this study. The sample consists of firmquarter observations from 1997 to 2008. Variable definitions are provided in Appendix A. All continuous variables are winsorized at the $1^{\text {st }}$ and $99^{\text {th }}$ percentiles. An observation is excluded from the regression analysis if any variable is missing.

\begin{tabular}{lrrrrr}
\hline \hline Variables & Mean & $\mathrm{P} 50$ & $\mathrm{SD}$ & $\mathrm{P} 25$ & $\mathrm{P} 75$ \\
\hline DA & 0.0451 & 0.0260 & 0.0579 & 0.0113 & 0.0535 \\
DD & -0.0517 & -0.0265 & 0.0711 & -0.0596 & -0.0109 \\
ABSSPI & 0.0074 & 0 & 0.0272 & 0 & 0.0017 \\
RES & 0.1138 & 0 & 0.3175 & 0 & 0 \\
RES_FRD & 0.0177 & 0 & 0.1317 & 0 & 0 \\
RMI & 1.1228 & 0.7643 & 1.1377 & 0.3279 & 1.5190 \\
RM2 & 0.7805 & 0.5391 & 0.8042 & 0.2379 & 1.0438 \\
RM & 1.3158 & 0.9321 & 1.2787 & 0.4159 & 1.7980 \\
CPGL & -0.0169 & 0 & 0.0873 & -0.0297 & 0.0251 \\
CPGL_TaxSen & -0.0038 & 0 & 0.0253 & -0.0055 & 0.0052 \\
CPGL_TaxInSen & -0.0031 & 0 & 0.0260 & -0.0025 & 0.0031 \\
Inst_ownership & 0.4799 & 0.4793 & 0.3044 & 0.2038 & 0.7351 \\
Size & 5.6543 & 5.5161 & 1.9523 & 4.2117 & 6.9566 \\
Age & 2.6171 & 2.4849 & 0.7034 & 2.0794 & 3.0910 \\
MB & 1.8848 & 1.2973 & 1.7629 & 0.8711 & 2.1634 \\
Loss & 0.2090 & 0 & 0.4066 & 0.013 & 0 \\
Leverage & 0.2307 & 0.1858 & 0.2310 & 0.0186 & 0.3564 \\
ROA & 0.0106 & 0.0267 & 0.0661 & 0.0016 & 0.0443 \\
Sales_volatility & 0.0639 & 0.0455 & 0.0608 & 0.0250 & 0.0805 \\
CFO_volatility & 0.0434 & 0.0322 & 0.0367 & 0.0201 & 0.0534 \\
Sales_growth & 0.2210 & 0.0885 & 0.7189 & -0.0422 & 0.2728 \\
Return_3m & 0.0068 & -0.0200 & 0.2999 & -0.1672 & 0.1323 \\
Return_6m & 0.0135 & -0.0419 & 0.4433 & -0.2524 & 0.1816 \\
Return_12m & 0.0433 & -0.0866 & 0.7158 & -0.3899 & 0.2602 \\
\hline \hline
\end{tabular}




\section{Table 2. Capital gains lock-in and discretionary accruals}

This table reports the results from the OLS regressions in which the dependent variable is $D A$. Firm fixed effects and time (year-quarter) fixed effects are included. Variable definitions are provided in Appendix A. All continuous variables are winsorized at the $1^{\text {st }}$ and $99^{\text {th }}$ percentiles. Standard errors double clustered to account for potential simultaneous correlation along firm and time dimensions are listed in the parentheses below the point estimates. $*, * *$, and $* * *$ denote significance at the $10 \%, 5 \%$, and $1 \%$ levels, respectively.

\begin{tabular}{|c|c|c|c|c|}
\hline Variables & Model 1 & Model 2 & Model 3 & Model 4 \\
\hline$C P G L$ & $\begin{array}{c}-0.0313 * * * \\
(0.0054)\end{array}$ & & & \\
\hline$C P G L_{-}$TaxSen $[A]$ & & $\begin{array}{c}-0.0677 * * * \\
(0.0121)\end{array}$ & $\begin{array}{c}-0.0684 * * * \\
(0.0125)\end{array}$ & $\begin{array}{c}-0.0676 * * * \\
(0.0125)\end{array}$ \\
\hline$C P G L \_T a x I n S e n[B]$ & & $\begin{array}{l}-0.0240 \\
(0.0167)\end{array}$ & $\begin{array}{l}-0.0243 \\
(0.0168)\end{array}$ & $\begin{array}{l}-0.0239 \\
(0.0167)\end{array}$ \\
\hline Inst_ownership & $\begin{array}{l}-0.0035 \\
(0.0023)\end{array}$ & $\begin{array}{l}-0.0036 \\
(0.0022)\end{array}$ & $\begin{array}{l}-0.0036 \\
(0.0022)\end{array}$ & $\begin{array}{l}-0.0036 \\
(0.0022)\end{array}$ \\
\hline Size & $\begin{array}{c}-0.0086 * * * \\
(0.0009)\end{array}$ & $\begin{array}{c}-0.0088 * * * \\
(0.0009)\end{array}$ & $\begin{array}{c}-0.0088 * * * \\
(0.0009)\end{array}$ & $\begin{array}{c}-0.0088 * * * \\
(0.0009)\end{array}$ \\
\hline Age & $\begin{array}{c}0.0006 \\
(0.0027)\end{array}$ & $\begin{array}{c}0.0009 \\
(0.0027)\end{array}$ & $\begin{array}{c}0.0009 \\
(0.0027)\end{array}$ & $\begin{array}{c}0.0009 \\
(0.0027)\end{array}$ \\
\hline$M B$ & $\begin{array}{l}0.0005^{*} \\
(0.0003)\end{array}$ & $\begin{array}{c}0.0004 \\
(0.0003)\end{array}$ & $\begin{array}{c}0.0004 \\
(0.0003)\end{array}$ & $\begin{array}{c}0.0004 \\
(0.0003)\end{array}$ \\
\hline Loss & $\begin{array}{l}0.0026^{* *} \\
(0.0010)\end{array}$ & $\begin{array}{c}0.0028 * * * \\
(0.0010)\end{array}$ & $\begin{array}{c}0.0028 * * * \\
(0.0010)\end{array}$ & $\begin{array}{c}0.0028 * * * \\
(0.0010)\end{array}$ \\
\hline Leverage & $\begin{array}{c}0.0152 * * * \\
(0.0031)\end{array}$ & $\begin{array}{c}0.0158 * * * \\
(0.0031)\end{array}$ & $\begin{array}{c}0.0158 * * * \\
(0.0031)\end{array}$ & $\begin{array}{c}0.0158 * * * \\
(0.0031)\end{array}$ \\
\hline$R O A$ & $\begin{array}{c}-0.1059 * * * \\
(0.0159)\end{array}$ & $\begin{array}{c}-0.1076 * * * \\
(0.0160)\end{array}$ & $\begin{array}{c}-0.1078 * * * \\
(0.0160)\end{array}$ & $\begin{array}{c}-0.1075 * * * \\
(0.0160)\end{array}$ \\
\hline Sales_volatility & $\begin{array}{l}-0.0011 \\
(0.0107)\end{array}$ & $\begin{array}{l}-0.0010 \\
(0.0108)\end{array}$ & $\begin{array}{l}-0.0010 \\
(0.0108)\end{array}$ & $\begin{array}{l}-0.0010 \\
(0.0108)\end{array}$ \\
\hline$C F O \_v o l a t i l i t y$ & $\begin{array}{c}0.2097 * * * \\
(0.0206)\end{array}$ & $\begin{array}{c}0.2104 * * * \\
(0.0207)\end{array}$ & $\begin{array}{c}0.2104 * * * \\
(0.0207)\end{array}$ & $\begin{array}{c}0.2103 * * * \\
(0.0207)\end{array}$ \\
\hline Sales_growth & $\begin{array}{c}0.0032 * * * \\
(0.0005)\end{array}$ & $\begin{array}{c}0.0031 * * * \\
(0.0005)\end{array}$ & $\begin{array}{c}0.0031 * * * \\
(0.0004)\end{array}$ & $\begin{array}{c}0.0031 * * * \\
(0.0004)\end{array}$ \\
\hline Return_12m & $\begin{array}{c}0.0001 \\
(0.0005)\end{array}$ & $\begin{array}{l}-0.0001 \\
(0.0005)\end{array}$ & & \\
\hline Return_6m & & & $\begin{array}{c}0.0001 \\
(0.0006)\end{array}$ & \\
\hline Return_3m & & & & $\begin{array}{l}-0.0003 \\
(0.0010)\end{array}$ \\
\hline Observations & 84,302 & 84,302 & 84,302 & 84,302 \\
\hline R-squared & 0.2675 & 0.2671 & 0.2671 & 0.2671 \\
\hline Firm FE & YES & YES & YES & YES \\
\hline Year-Quarter FE & YES & YES & YES & YES \\
\hline SE clustered by & Firm and Time & Firm and Time & Firm and Time & Firm and Time \\
\hline $\begin{array}{l}\beta(\mathrm{A})<\beta(\mathrm{B}), p \text {-value of } \\
\text { one-tailed test }\end{array}$ & & $0.0320 * *$ & $0.0317 * *$ & $0.0328 * *$ \\
\hline
\end{tabular}




\section{Table 3. Capital gains lock-in and accrual quality}

This table reports the results from the OLS regressions in which the dependent variable is $D D$. Firm fixed effects and time (year-quarter) fixed effects are included. Variable definitions are provided in Appendix A. All continuous variables are winsorized at the $1^{\text {st }}$ and $99^{\text {th }}$ percentiles. Standard errors double clustered to account for potential simultaneous correlation along firm and time dimensions are listed in the parentheses below the point estimates. $*, * *$, and $* * *$ denote significance at the $10 \%, 5 \%$, and $1 \%$ levels, respectively.

\begin{tabular}{|c|c|c|}
\hline Variables & Model 1 & Model 2 \\
\hline$C P G L$ & $\begin{array}{c}0.0335^{* * *} \\
(0.0064)\end{array}$ & \\
\hline$C P G L \_T a x \operatorname{Sen}[A]$ & & $\begin{array}{l}0.0841 * * * \\
(0.0169)\end{array}$ \\
\hline CPGL_TaxInSen $[B]$ & & $\begin{array}{c}0.0120 \\
(0.0167)\end{array}$ \\
\hline Inst_ownership & $\begin{array}{l}-0.0006 \\
(0.0030)\end{array}$ & $\begin{array}{l}-0.0006 \\
(0.0029)\end{array}$ \\
\hline Size & $\begin{array}{l}0.0102 * * * \\
(0.0012)\end{array}$ & $\begin{array}{c}0.0105^{* * *} \\
(0.0012)\end{array}$ \\
\hline Age & $\begin{array}{l}-0.0029 \\
(0.0036)\end{array}$ & $\begin{array}{l}-0.0033 \\
(0.0036)\end{array}$ \\
\hline$M B$ & $\begin{array}{c}-0.0014 * * * \\
(0.0004)\end{array}$ & $\begin{array}{c}-0.0013 * * * \\
(0.0004)\end{array}$ \\
\hline Loss & $\begin{array}{l}-0.0016 \\
(0.0015)\end{array}$ & $\begin{array}{l}-0.0018 \\
(0.0015)\end{array}$ \\
\hline Leverage & $\begin{array}{c}-0.0146 * * * \\
(0.0037)\end{array}$ & $\begin{array}{c}-0.0153 * * * \\
(0.0037)\end{array}$ \\
\hline$R O A$ & $\begin{array}{c}0.1331 * * * \\
(0.0180)\end{array}$ & $\begin{array}{c}0.1348 * * * \\
(0.0180)\end{array}$ \\
\hline Sales_volatility & $\begin{array}{c}0.0130 \\
(0.0138)\end{array}$ & $\begin{array}{c}0.0127 \\
(0.0138)\end{array}$ \\
\hline CFO_volatility & $\begin{array}{c}-0.2020 * * * \\
(0.0271)\end{array}$ & $\begin{array}{l}-0.2025 * * * \\
(0.0271)\end{array}$ \\
\hline Sales_growth & $\begin{array}{c}-0.0023 * * * \\
(0.0006)\end{array}$ & $\begin{array}{l}-0.0023 * * * \\
(0.0006)\end{array}$ \\
\hline Return_12m & $\begin{array}{c}0.0004 \\
(0.0006)\end{array}$ & $\begin{array}{c}0.0006 \\
(0.0006)\end{array}$ \\
\hline Observations & 84,123 & 84,123 \\
\hline R-squared & 0.2835 & 0.2832 \\
\hline Firm FE & YES & YES \\
\hline Year-Quarter FE & YES & YES \\
\hline SE clustered by & Firm and Time & Firm and Time \\
\hline $\begin{array}{l}\beta(\mathrm{A})>\beta(\mathrm{B}), p \text {-value of one-tailed } \\
\text { test }\end{array}$ & & $0.0025 * * *$ \\
\hline
\end{tabular}


Table 4. Capital gains lock-in and special items

This table reports the results from the OLS regressions in which the dependent variable is ABSSPI. Firm fixed effects and time (year-quarter) fixed effects are included. Variable definitions are provided in Appendix A. All continuous variables are winsorized at the $1^{\text {st }}$ and $99^{\text {th }}$ percentiles. Standard errors double clustered to account for potential simultaneous correlation along firm and time dimensions are listed in the parentheses below the point estimates. $*, * *$, and $* * *$ denote significance at the $10 \%, 5 \%$, and $1 \%$ levels, respectively.

\begin{tabular}{|c|c|c|}
\hline Variables & Model 1 & Model 2 \\
\hline$C P G L$ & $\begin{array}{c}-0.0304 * * * \\
(0.0055)\end{array}$ & \\
\hline CPGL_TaxSen [A] & & $\begin{array}{c}-0.0624 * * * \\
(0.0106)\end{array}$ \\
\hline CPGL_TaxInSen [B] & & $\begin{array}{c}-0.0284 * * \\
(0.0125)\end{array}$ \\
\hline Inst_ownership & $\begin{array}{l}-0.0022^{*} \\
(0.0013)\end{array}$ & $\begin{array}{l}-0.0023 * \\
(0.0012)\end{array}$ \\
\hline Size & $\begin{array}{c}-0.0019 * * \\
(0.0009)\end{array}$ & $\begin{array}{c}-0.0021 * * \\
(0.0009)\end{array}$ \\
\hline Age & $\begin{array}{c}0.0001 \\
(0.0016)\end{array}$ & $\begin{array}{c}0.0004 \\
(0.0016)\end{array}$ \\
\hline$M B$ & $\begin{array}{l}-0.0001 \\
(0.0002)\end{array}$ & $\begin{array}{l}-0.0002 \\
(0.0002)\end{array}$ \\
\hline Loss & $\begin{array}{l}0.0013 * \\
(0.0007)\end{array}$ & $\begin{array}{c}0.0015^{* *} \\
(0.0007)\end{array}$ \\
\hline Leverage & $\begin{array}{c}0.0101 * * * \\
(0.0019)\end{array}$ & $\begin{array}{c}0.0107 * * * \\
(0.0019)\end{array}$ \\
\hline$R O A$ & $\begin{array}{c}-0.0593 * * * \\
(0.0086)\end{array}$ & $\begin{array}{c}-0.0609 * * * \\
(0.0087)\end{array}$ \\
\hline Sales_volatility & $\begin{array}{l}-0.0077 \\
(0.0049)\end{array}$ & $\begin{array}{l}-0.0075 \\
(0.0049)\end{array}$ \\
\hline$C F O \_$volatility & $\begin{array}{l}-0.0031 \\
(0.0072)\end{array}$ & $\begin{array}{l}-0.0025 \\
(0.0072)\end{array}$ \\
\hline Sales_growth & $\begin{array}{l}-0.0004 * * \\
(0.0002)\end{array}$ & $\begin{array}{c}-0.0005^{* *} \\
(0.0002)\end{array}$ \\
\hline Return_12m & $\begin{array}{c}-0.0008^{* * *} \\
(0.0003)\end{array}$ & $\begin{array}{c}-0.0010 * * * \\
(0.0003)\end{array}$ \\
\hline Observations & 92,429 & 92,429 \\
\hline R-squared & 0.1777 & 0.1761 \\
\hline Firm FE & YES & YES \\
\hline Year-Quarter FE & YES & YES \\
\hline SE clustered by & Firm and Time & Firm and Time \\
\hline$\beta(\mathrm{A})<\beta(\mathrm{B}), p$-value of one-tailed test & & $0.0129 * *$ \\
\hline
\end{tabular}


Table 5. Capital gains lock-in and real earnings management

This table reports the results from the OLS regressions in which the dependent variable are three real earnings management measures. The dependent variable in column 1 is $R M 1$. In column 2 , the dependent variable is $R M 2$. The dependent variable in column 3 is $R M$. Firm fixed effects and time (year-quarter) fixed effects are included. Variable definitions are provided in Appendix A. All continuous variables are winsorized at the $1^{\text {st }}$ and $99^{\text {th }}$ percentiles. Standard errors double clustered to account for potential simultaneous correlation along firm and time dimensions are listed in the parentheses below the point estimates. $*, * *$, and $* * *$ denote significance at the $10 \%, 5 \%$, and $1 \%$ levels, respectively.

\begin{tabular}{|c|c|c|c|}
\hline Variables & Model 1. RMI & Model 2. $R M 2$ & Model 3. $R M$ \\
\hline$C P G L \_T a x \operatorname{Sen}[A]$ & $\begin{array}{l}-0.5663 * * \\
(0.2664)\end{array}$ & $\begin{array}{l}-0.3412^{*} \\
(0.1780)\end{array}$ & $\begin{array}{c}-0.7454 * * \\
(0.2970)\end{array}$ \\
\hline CPGL_TaxInSen $[B]$ & $\begin{array}{c}0.0543 \\
(0.2206)\end{array}$ & $\begin{array}{c}0.2725 * * \\
(0.1321)\end{array}$ & $\begin{array}{c}0.3723 \\
(0.2595)\end{array}$ \\
\hline Inst_ownership & $\begin{array}{c}-0.1096 * * \\
(0.0497)\end{array}$ & $\begin{array}{c}-0.0902 * * \\
(0.0354)\end{array}$ & $\begin{array}{c}-0.1947 * * * \\
(0.0578)\end{array}$ \\
\hline Size & $\begin{array}{l}-0.2286 * * * \\
(0.0240)\end{array}$ & $\begin{array}{l}-0.1142 * * * \\
(0.0134)\end{array}$ & $\begin{array}{l}-0.2153^{* * *} \\
(0.0241)\end{array}$ \\
\hline Age & $\begin{array}{l}-0.0365 \\
(0.0576)\end{array}$ & $\begin{array}{l}-0.0204 \\
(0.0343)\end{array}$ & $\begin{array}{l}-0.0893 \\
(0.0625)\end{array}$ \\
\hline$M B$ & $\begin{array}{l}0.0719 * * * \\
(0.0094)\end{array}$ & $\begin{array}{l}0.0393 * * * \\
(0.0052)\end{array}$ & $\begin{array}{c}0.0769 * * * \\
(0.0086)\end{array}$ \\
\hline Loss & $\begin{array}{c}0.0151 \\
(0.0206)\end{array}$ & $\begin{array}{c}0.0213 \\
(0.0156)\end{array}$ & $\begin{array}{c}0.0084 \\
(0.0213)\end{array}$ \\
\hline Leverage & $\begin{array}{l}0.1267 * \\
(0.0632)\end{array}$ & $\begin{array}{c}0.0059 \\
(0.0385)\end{array}$ & $\begin{array}{l}-0.0267 \\
(0.0605)\end{array}$ \\
\hline$R O A$ & $\begin{array}{l}-0.4379 \\
(0.3952)\end{array}$ & $\begin{array}{l}1.1091 * * * \\
(0.1921)\end{array}$ & $\begin{array}{l}1.9126 * * * \\
(0.5202)\end{array}$ \\
\hline Sales_volatility & $\begin{array}{l}0.4615^{*} \\
(0.2552)\end{array}$ & $\begin{array}{l}-0.0410 \\
(0.1696)\end{array}$ & $\begin{array}{c}0.2375 \\
(0.2811)\end{array}$ \\
\hline$C F O \_$volatility & $\begin{array}{c}0.8644 \\
(0.5911)\end{array}$ & $\begin{array}{c}3.3654 * * * \\
(0.4544)\end{array}$ & $\begin{array}{l}3.3781 * * * \\
(0.7045)\end{array}$ \\
\hline Sales_growth & $\begin{array}{c}0.1010 * * * \\
(0.0128)\end{array}$ & $\begin{array}{c}0.0461 * * * \\
(0.0091)\end{array}$ & $\begin{array}{c}0.1061 * * * \\
(0.0142)\end{array}$ \\
\hline Return_12m & $\begin{array}{l}-0.0015 \\
(0.0095)\end{array}$ & $\begin{array}{c}0.0124^{*} \\
(0.0067)\end{array}$ & $\begin{array}{c}0.0187^{*} \\
(0.0108)\end{array}$ \\
\hline Observations & 73,874 & 74,501 & 73,163 \\
\hline R-squared & 0.5737 & 0.3396 & 0.4566 \\
\hline Firm FE & YES & YES & YES \\
\hline Year-Quarter FE & YES & YES & YES \\
\hline SE clustered by & $\begin{array}{l}\text { Firm and } \\
\text { Time }\end{array}$ & $\begin{array}{l}\text { Firm and } \\
\text { Time }\end{array}$ & $\begin{array}{l}\text { Firm and } \\
\text { Time }\end{array}$ \\
\hline $\begin{array}{l}\beta(\mathrm{A})<\beta(\mathrm{B}), p \text {-value of one-tailed } \\
\text { test }\end{array}$ & $0.0678 *$ & $0.0120 * *$ & $0.0126^{* *}$ \\
\hline
\end{tabular}




\section{Table 6. Capital gains lock-in and restatement}

This table reports the results from the logit regressions in which the dependent variables are related to accounting restatement. In column 1 and column 2, the dependent variable is $R E S$. The dependent variable in column 3 and column 4 is $R E S$ FRD. Firm fixed effects and time (year-quarter) fixed effects are included. Variable definitions are provided in Appendix A. All continuous variables are winsorized at the $1^{\text {st }}$ and $99^{\text {th }}$ percentiles. Standard errors are listed in the parentheses below the point estimates. *, $* *$, and $* * *$ denote significance at the $10 \%, 5 \%$, and $1 \%$ levels, respectively.

\begin{tabular}{|c|c|c|c|c|}
\hline Variables & Model 1 & Model 2 & Model 3 & Model 4 \\
\hline$C P G L$ & $\begin{array}{c}0.1071 \\
(0.2204)\end{array}$ & & $\begin{array}{c}0.5960 \\
(0.5714)\end{array}$ & \\
\hline CPGL_TaxSen $[A]$ & & $\begin{array}{c}-2.0457 * * \\
(0.7988)\end{array}$ & & $\begin{array}{c}-6.3727 * * * \\
(2.0974)\end{array}$ \\
\hline CPGL_TaxInSen $[B]$ & & $\begin{array}{l}1.8153 * * \\
(0.7315)\end{array}$ & & $\begin{array}{c}2.8836 \\
(1.8210)\end{array}$ \\
\hline Inst_ownership & $\begin{array}{c}0.1272 \\
(0.1263)\end{array}$ & $\begin{array}{c}0.1495 \\
(0.1265)\end{array}$ & $\begin{array}{c}0.7368 * * \\
(0.3317)\end{array}$ & $\begin{array}{c}0.8623 * * * \\
(0.3321)\end{array}$ \\
\hline Size & $\begin{array}{c}0.5416^{* * *} \\
(0.0396)\end{array}$ & $\begin{array}{c}0.5415 * * * \\
(0.0396)\end{array}$ & $\begin{array}{c}1.3367 * * * \\
(0.1067)\end{array}$ & $\begin{array}{c}1.3413 * * * \\
(0.1071)\end{array}$ \\
\hline Age & $\begin{array}{c}0.4432 * * * \\
(0.1328)\end{array}$ & $\begin{array}{c}0.4484 * * * \\
(0.1328)\end{array}$ & $\begin{array}{c}2.0385 * * * \\
(0.3693)\end{array}$ & $\begin{array}{c}2.1314 * * * \\
(0.3709)\end{array}$ \\
\hline$M B$ & $\begin{array}{c}0.0559 * * * \\
(0.0154)\end{array}$ & $\begin{array}{c}0.0598 * * * \\
(0.0155)\end{array}$ & $\begin{array}{c}0.1871 * * * \\
(0.0403)\end{array}$ & $\begin{array}{c}0.2194 * * * \\
(0.0405)\end{array}$ \\
\hline Loss & $\begin{array}{c}0.0138 \\
(0.0540)\end{array}$ & $\begin{array}{c}0.0089 \\
(0.0540)\end{array}$ & $\begin{array}{c}-0.1099 \\
(0.1402)\end{array}$ & $\begin{array}{l}-0.1562 \\
(0.1408)\end{array}$ \\
\hline Leverage & $\begin{array}{c}0.6571 * * * \\
(0.1272)\end{array}$ & $\begin{array}{c}0.6411 * * * \\
(0.1273)\end{array}$ & $\begin{array}{c}0.9565^{* * *} * \\
(0.3238)\end{array}$ & $\begin{array}{c}0.9075 * * * \\
(0.3231)\end{array}$ \\
\hline$R O A$ & $\begin{array}{l}-0.7520^{*} \\
(0.4413)\end{array}$ & $\begin{array}{l}-0.7057 \\
(0.4409)\end{array}$ & $\begin{array}{c}-2.5610 * * \\
(1.1497)\end{array}$ & $\begin{array}{l}-2.2451^{*} \\
(1.1525)\end{array}$ \\
\hline Sales_volatility & $\begin{array}{c}2.1021 * * * \\
(0.5003)\end{array}$ & $\begin{array}{c}2.0921 * * * \\
(0.5003)\end{array}$ & $\begin{array}{l}-1.6239 \\
(1.1380)\end{array}$ & $\begin{array}{l}-1.6271 \\
(1.1395)\end{array}$ \\
\hline CFO_volatility & $\begin{array}{l}1.3295 \\
(1.0050)\end{array}$ & $\begin{array}{l}1.3295 \\
(1.0065)\end{array}$ & $\begin{array}{c}- \\
10.1053 * * * \\
(2.8219)\end{array}$ & $\begin{array}{c}10.6647 * * * \\
(2.8376)\end{array}$ \\
\hline Sales_growth & $\begin{array}{c}-0.0735 * * * \\
(0.0263)\end{array}$ & $\begin{array}{c}-0.0722 * * * \\
(0.0263)\end{array}$ & $\begin{array}{l}-0.0542 \\
(0.0586)\end{array}$ & $\begin{array}{c}-0.0493 \\
(0.0588)\end{array}$ \\
\hline Return_12m & $\begin{array}{c}0.0665 * * * \\
(0.0227)\end{array}$ & $\begin{array}{c}0.0714 * * * \\
(0.0226)\end{array}$ & $\begin{array}{l}-0.0737 \\
(0.0573)\end{array}$ & $\begin{array}{c}-0.0392 \\
(0.0569)\end{array}$ \\
\hline Observations & 33,013 & 33,013 & 5,306 & 5,306 \\
\hline Firm FE & YES & YES & YES & YES \\
\hline Year-Quarter FE & YES & YES & YES & YES \\
\hline$\beta(\mathrm{A})<\beta(\mathrm{B}), p$-value of one-tailed test & & $0.0014 * * *$ & & $0.0027 * * *$ \\
\hline
\end{tabular}


Table 7. Capital gains lock-in, discretionary accruals, and the capital gains tax rate

This table reports the results from the OLS regressions in which the dependent variable is $D A$. The sample period is 1997-2008 in column 1, 2002-2004 in column 2, and 2001-2005 in column 3. Firm fixed effects and time (year-quarter) fixed effects are included. Variable definitions are provided in Appendix A. All continuous variables are winsorized at the $1^{\text {st }}$ and $99^{\text {th }}$ percentiles. Standard errors double clustered to account for potential simultaneous correlation along firm and time dimensions are listed in the parentheses below the point estimates. $*, * *$, and $* * *$ denote significance at the $10 \%, 5 \%$, and $1 \%$ levels, respectively.

\begin{tabular}{|c|c|c|c|}
\hline Variables & Model 1. 1997-2008 & Model 2. 2002-2004 & Model 3. 2001-2005 \\
\hline CPGL_TaxSen & $\begin{array}{c}0.2159 \\
(0.1299)\end{array}$ & & \\
\hline CPGL_TaxSen $\times$ Taxrate & $\begin{array}{c}-0.0148 * * \\
(0.0068)\end{array}$ & & \\
\hline CPGL_TaxInSen & $\begin{array}{c}0.0611 \\
(0.1080)\end{array}$ & & \\
\hline CPGL_TaxInSen $\times$ Taxrate & $\begin{array}{l}-0.0049 \\
(0.0060)\end{array}$ & & \\
\hline CPGL_TaxSen $\times T R 2[A]$ & & $\begin{array}{l}-0.0714^{*} \\
(0.0362)\end{array}$ & $\begin{array}{c}-0.1039 * * * \\
(0.0269)\end{array}$ \\
\hline$C P G L \_T a x I n S e n \times T R 2[B]$ & & $\begin{array}{l}-0.0322 \\
(0.0260)\end{array}$ & $\begin{array}{c}-0.0608 * * \\
(0.0289)\end{array}$ \\
\hline CPGL_TaxSen $\times T R 3[C]$ & & $\begin{array}{c}0.0663 \\
(0.0573)\end{array}$ & $\begin{array}{c}0.0387 \\
(0.0487)\end{array}$ \\
\hline CPGL_TaxInSen $\times T R 3[D]$ & & $\begin{array}{l}-0.0228 \\
(0.0428)\end{array}$ & $\begin{array}{l}-0.0232 \\
(0.0358)\end{array}$ \\
\hline Inst_ownership & $\begin{array}{l}-0.0035 \\
(0.0022)\end{array}$ & $\begin{array}{l}-0.0108 * \\
(0.0054)\end{array}$ & $\begin{array}{l}-0.0029 \\
(0.0055)\end{array}$ \\
\hline Size & $\begin{array}{c}-0.0092 * * * \\
(0.0009)\end{array}$ & $\begin{array}{c}-0.0157 * * * \\
(0.0032)\end{array}$ & $\begin{array}{c}-0.0137 * * * \\
(0.0021)\end{array}$ \\
\hline Age & $\begin{array}{c}0.0020 \\
(0.0026)\end{array}$ & $\begin{array}{l}-0.0323 \\
(0.0202)\end{array}$ & $\begin{array}{c}-0.0307 * * * \\
(0.0099)\end{array}$ \\
\hline$M B$ & $\begin{array}{c}0.0003 \\
(0.0003)\end{array}$ & $\begin{array}{l}-0.0002 \\
(0.0008)\end{array}$ & $\begin{array}{l}-0.0005 \\
(0.0004)\end{array}$ \\
\hline Loss & $\begin{array}{c}0.0028 * * * \\
(0.0010)\end{array}$ & $\begin{array}{c}0.0050 * * * \\
(0.0015)\end{array}$ & $\begin{array}{c}0.0042 * * * \\
(0.0013)\end{array}$ \\
\hline Leverage & $\begin{array}{c}0.0163 * * * \\
(0.0031)\end{array}$ & $\begin{array}{r}0.0182 * * \\
(0.0069)\end{array}$ & $\begin{array}{l}0.0123 * * \\
(0.0044)\end{array}$ \\
\hline$R O A$ & $\begin{array}{c}-0.1074 * * * \\
(0.0160)\end{array}$ & $\begin{array}{l}-0.0615 \\
(0.0371)\end{array}$ & $\begin{array}{c}-0.0804 * * \\
(0.0298)\end{array}$ \\
\hline Sales_volatility & $\begin{array}{l}-0.0011 \\
(0.0108)\end{array}$ & $\begin{array}{c}-0.0612^{* *} \\
(0.0200)\end{array}$ & $\begin{array}{l}-0.0343 \\
(0.0218)\end{array}$ \\
\hline $\mathrm{CFO}$ _volatility & $\begin{array}{l}0.2102 * * * \\
(0.0206)\end{array}$ & $\begin{array}{c}0.3379 * * * \\
(0.0743)\end{array}$ & $\begin{array}{l}0.2420 * * * \\
(0.0457)\end{array}$ \\
\hline Sales_growth & $\begin{array}{c}0.0032 * * * \\
(0.0005)\end{array}$ & $\begin{array}{c}0.0037 * * * \\
(0.0010)\end{array}$ & $\begin{array}{c}0.0037 * * * \\
(0.0007)\end{array}$ \\
\hline Return_12m & $\begin{array}{l}-0.0000 \\
(0.0005)\end{array}$ & $\begin{array}{l}-0.0008 \\
(0.0008)\end{array}$ & $\begin{array}{c}0.0001 \\
(0.0008)\end{array}$ \\
\hline Observations & 84,302 & 21,268 & 35,344 \\
\hline R-squared & 0.2674 & 0.3187 & 0.2959 \\
\hline Firm FE & YES & YES & YES \\
\hline Year-Quarter FE & YES & YES & YES \\
\hline SE clustered by & Firm and Time & Firm and Time & Firm and Time \\
\hline$\beta(\mathrm{A})<\beta(\mathrm{C})$, $\mathrm{p}$-value of one-tailed test & & $0.0218 * *$ & $0.0048 * * *$ \\
\hline$\beta(B)<\beta(D), p$-value of one-tailed test & & 0.4262 & 0.2041 \\
\hline$\beta(A)-\beta(B)<\beta(C)-\beta(D), p$-value of one-tailed test & & $0.0311 * *$ & $0.0577 *$ \\
\hline
\end{tabular}


Table 8: Mechanism of capital gains lock-in effect

This table reports the results from the OLS regressions in which the dependent variable is $D A$. Firm fixed effects and time (year-quarter) fixed effects are included. Variable definitions are provided in Appendix A. All continuous variables are winsorized at the $1^{\text {st }}$ and $99^{\text {th }}$ percentiles. Standard errors double clustered to account for potential simultaneous correlation along firm and time dimensions are listed in the parentheses below the point estimates. $*, * *$, and $* * *$ denote significance at the $10 \%, 5 \%$, and $1 \%$ levels, respectively.

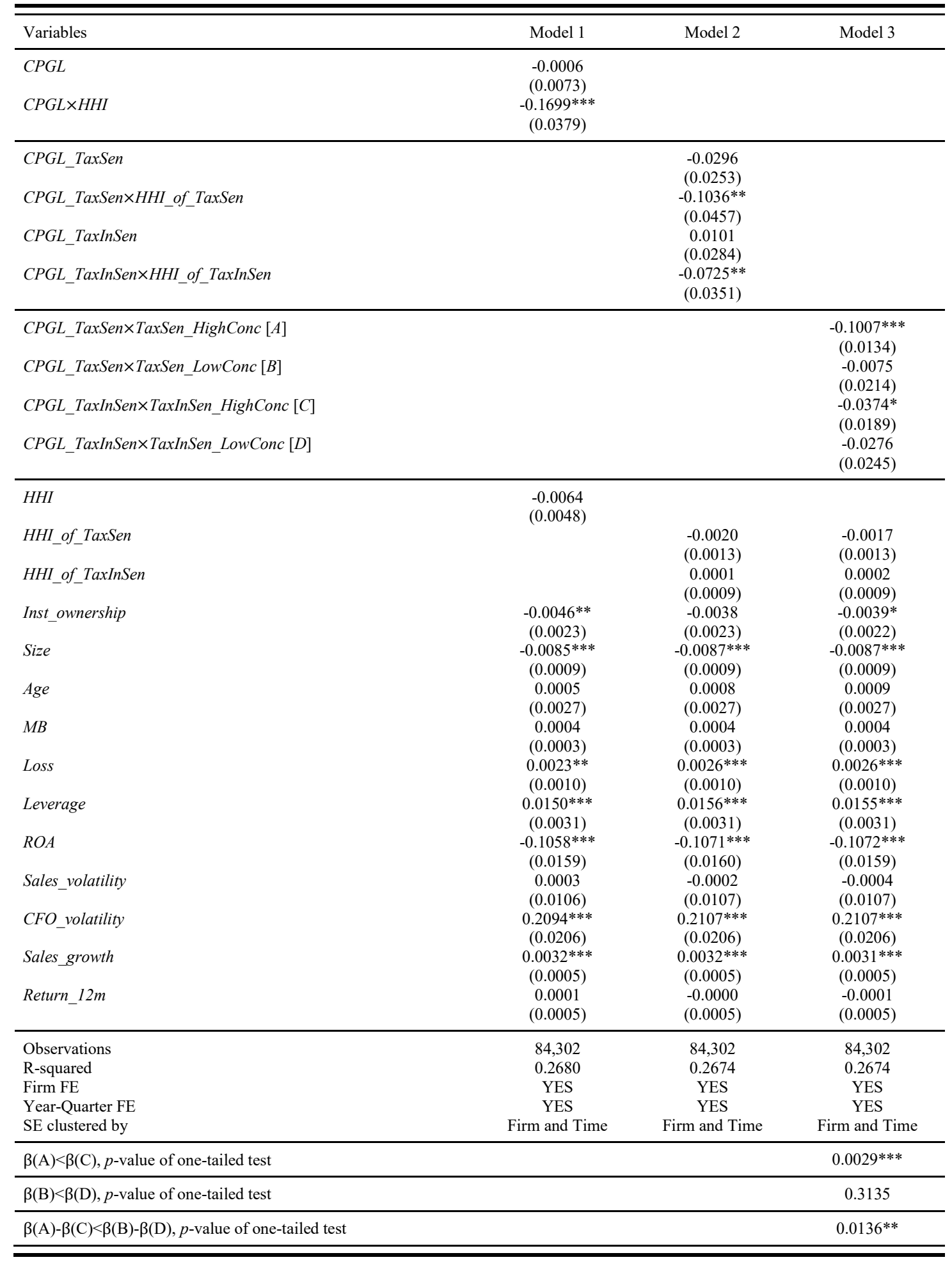

